NBER WORKING PAPER SERIES

\title{
FINANCE, INEQUALITY, AND POVERTY: CROSS-COUNTRY EVIDENCE
}

\author{
Thorsten Beck \\ Asli Demirguc-Kunt \\ Ross Levine \\ Working Paper 10979 \\ http://www.nber.org/papers/w10979 \\ NATIONAL BUREAU OF ECONOMIC RESEARCH \\ 1050 Massachusetts Avenue \\ Cambridge, MA 02138 \\ December 2004
}

Beck and Demirgüç-Kunt: World Bank; Levine: University of Minnesota and the NBER. We would like to thank Aart Kraay for sharing his data with us. Biagio Bossone, Francois Bourguignon, Gerard Caprio, Maria Carkovic, Michael Fuchs, Alan Gelb, Patrick Honohan, Aart Kraay, Ashoka Mody, Martin Ravallion, and seminar participants at Brown University, the University of Minnesota, and the World Bank provided helpful comments. We thank Meghana Ayyagari and April Knill for outstanding research assistance. This paper's findings, interpretations, and conclusions are entirely those of the authors and do not necessarily represent the views of the World Bank, its Executive Directors, or the countries they represent. The views expressed herein are those of the author(s) and do not necessarily reflect the views of the National Bureau of Economic Research.

(C) 2004 by Thorsten Beck, Asli Demirguc-Kunt, and Ross Levine. All rights reserved. Short sections of text, not to exceed two paragraphs, may be quoted without explicit permission provided that full credit, including (C) notice, is given to the source. 
Finance, Inequality, and Poverty: Cross-Country Evidence

Thorsten Beck, Asli Demirguc-Kunt, and Ross Levine

NBER Working Paper No. 10979

December 2004

JEL No. O11, O16, G00

\section{$\underline{\text { ABSTRACT }}$}

While substantial research finds that financial development boosts overall economic growth, we study whether financial development disproportionately raises the incomes of the poor and alleviates poverty. Using a broad cross-country sample, we distinguish among competing theoretical predictions about the impact of financial development on changes in income distribution and poverty alleviation. We find that financial development reduces income inequality by disproportionately boosting the incomes of the poor. Countries with better-developed financial intermediaries experience faster declines in measures of both poverty and income inequality. These results are robust to controlling for other country characteristics and potential reverse causality.

Throsten Beck

World Bank

tbeck@worldbank.org

Asli Demirguc-Kunt

World Bank

ademirguckunt@worldbank.org

Ross Levine

Finance Department, Room 3-257

Carlson School of Management

University of Minnesota

321 19th Avenue South

Minneapolis, MN 55455

and NBER

rlevine@csom.umn.edu 


\section{Introduction}

Stunningly high levels of poverty characterize much of the world. In 2001, 2.7 billion

people, more than half of the earth's inhabitants, lived on less than $\$ 2$ a day, and 1.1 billion lived on less than $\$ 1$ a day. ${ }^{1}$ Even these figures mask the extremes plaguing some parts of the world. In South Asia and Sub-Saharan Africa, only one-quarter of the people live on more than $\$ 2$ per day.

In accounting for changes in poverty, the literature notes that poverty alleviation can be decomposed into two parts: Faster economic growth and changes in the distribution of income. Indeed, depending on the precise definition of poverty, an arithmetic identity links poverty alleviation, growth, and changes in income distribution (Bourguignon, 2004). ${ }^{2}$ Besley and Burgesss (2003) illustrate the potential importance of both growth and changes in income distribution. They calculate that (1) developing countries need a GDP per capita growth rate of 3.8 percent to cut poverty in half by 2015, which is twice the growth rate of recent decades, and (2) a one standard deviation decline in the Gini coefficient of inequality would cut poverty by about half in regions with highly skewed income distributions such as Latin America and Africa. ${ }^{3}$ Thus, both GDP per capita growth and changes in income distribution may reduce poverty. ${ }^{4}$

Although a large literature finds that financial development produces faster economic growth, it is unclear whether financial development alleviates poverty. The bulk of existing

\footnotetext{
${ }^{1}$ These are based on Purchasing Power Parity exchange rates from the World Bank.

${ }^{2}$ For example, let $Y_{P}$ equal the per capita income of the lowest quintile, $Y$ equals average income per capita, and $L$ is the Lorenz curve which related the share of income received to the share of the population. Then, $\mathrm{Y}_{\mathrm{p}}=\mathrm{Y}^{*} \mathrm{~L}(0.2) / 0.2$. Now differentiate with respect to time and compute growth rates, letting $\mathrm{g}(\mathrm{x})$ represent the growth rate of variable $\mathrm{x}$. This yields $g\left(Y_{p}\right)=g(Y)+g(L(0.2)$. The growth of per capita income of the poorest quintile equals the growth of average per capita income plus the growth of the Lorenz curve, which captures changes in income distribution. ${ }^{3}$ In terms of income inequality, the poorest fifth of the families in the average country received less than $6 \%$ of that nation's Gross Domestic Product (GDP). This statistic examines income inequality within each country and then averages across countries. When focusing on people, not countries, world income is even more skewed. According the UN Development Report, the poorest 20 percent of the people receive less than $1.5 \%$ of the world's income.

${ }^{4}$ In terms of determining whether growth or income distribution changes accounts for more of poverty alleviation, Kraay (2004) finds that growth accounts for the bulk of poverty reductions in a broad cross-country study, while Ravallion (2001) provides specific country examples where both matter for poverty alleviation.
} 
empirical research suggests that financial development is positively associated with growth and this relationship is not due to reverse causality. ${ }^{5}$ Thus, if financial development does not intensify income inequality, financial development will help reduce poverty by boosting overall economic growth (Dollar and Kraay 2002). But, researchers have not determined whether financial development benefits the whole population, whether it primarily benefits the rich, or whether financial development disproportionately helps the poor.

This paper examines the relationship between financial development and both changes in the distribution of income and changes in the level of poverty. We do not reexamine the finance-growth link, nor do we reexamine the relationship between financial development and the level of income inequality (Clarke, Xu, and Zou, 2003) or the level of poverty (Honohan, 2004a). Rather, we provide the first assessment of the impact of financial development on changes in income inequality and changes in poverty. Thus, our approach complements the finance and growth literature by examining whether financial development exerts a disproportionately large influence on the poor.

Theory provides conflicting predictions about the relationship between financial development and changes in poverty and income distribution. Some models imply that financial development enhances growth and reduces inequality. Financial market imperfections, such as informational asymmetries, transactions costs, and contract enforcement costs, may be especially binding on poor entrepreneurs who lack collateral, credit histories, and connections. These credit constraints will impede the flow of capital to poor individuals with high-return projects (Galor and Zeira, 1993), ${ }^{6}$ thereby reducing the efficiency of capital allocation and intensifying income

\footnotetext{
${ }^{5}$ While much research indicates that finance causes growth, considerable debate remains. For reviews of this literature, see Levine (1997, 2005). Aghion, Howitt, and Mayer-Foulkes (2005) raise serious questions about whether the financial development affects steady-state growth, and instead find that finance influences the rate of convergence.

${ }^{6}$ Banerjee and Newman (1993) and Aghion and Bolton (1997) introduce moral-hazard considerations with limited liability as the explicit financial market imperfection and study the impact on income distribution and growth. Benabou (1996), Mookherjee and Ray (2003), and Aghion and Howitt (1998, chapter 1) provide additional theoretical contributions on the linkages between inequality and economic growth.
} 
inequality. From this perspective, financial development reduces poverty by (i) disproportionately relaxing credit constraints on the poor and reducing income inequality and (ii) improving the allocation of capital and accelerating growth.

Other theories, however, question whether financial development reduces poverty. Some research suggests that the poor primarily rely on informal, family connections for capital, so that improvements in the formal financial sector primarily help the rich. ${ }^{7}$ Along these lines, Greenwood and Jovanovic (1990) develop a model that predicts a nonlinear relationship between financial development and income inequality during the process of economic development. At early stages of development, only the rich can afford to access and profit from financial markets so that financial development intensifies income inequality. At higher levels of economic development, financial development helps an increasing proportion of society. Furthermore, some models imply that if financial development reduces income inequality, this could slow aggregate growth and increase poverty. Specifically, if the rich save more than the poor, and financial development reduces income inequality, this could reduce aggregate savings and slow growth with adverse ramifications on poverty (Bourguignon, 2001a). ${ }^{8}$ Thus, empirical evidence on the impact of finance on the distribution of income and poverty will help distinguish among competing theoretical predictions.

Methodologically, this paper assesses the relationship between financial development, poverty alleviation, and changes in the distribution of income using broad cross-country comparisons. Since different problems plague income distribution and poverty data, we use both to assess the robustness of the results. More specifically, we use two specifications to examine the

\footnotetext{
${ }^{7}$ See discussions surrounding this theme in Haber, et al. (2003) and Bourguignon and Verdier (2000). But, more competitive financial markets may permit greater access to financial services (Rajan and Zingales, 2003).

${ }^{8}$ Galor and Moav (2005) develop a model that integrates two themes in the inequality and growth literature. Under the assumption that savings rates are an increasing function of wealth, inequality positively impacts growth at early stages of economic development when physical capital accumulation is the key source of growth. At later stages of development, credit market imperfections become crucial as human capital accumulation becomes the prime engine of growth. Thus, income equality ameliorates the adverse implications of credit constraints on human capital accumulation with positive ramifications on economic growth.
} 
relationship between finance and income distribution and two additional specifications to investigate the finance-poverty alleviation nexus. First, we examine the impact of financial development on the growth rate of the income of each economy's poorest 20 percent. We assess the effect of finance on income growth of the poor while controlling for average per capita GDP growth. Although income growth of the poor is not a consistent measure of poverty across countries at different levels of economic development, this specification provides information on whether financial development influences the poorest quintile differently from its effect on average growth. By conditioning on average growth, we test whether financial development exerts a disproportionately large impact on the poor. Second, we continue our assessment of the distributional consequences of financial development by examining the growth rate of the Gini coefficient, which measures deviations from perfect income equality. Again, by controlling for average per capita GDP growth, we provide information on how financial development alters the distribution of income beyond its impact on aggregate growth. Then, we turn to direct measures of poverty alleviation. In our third specification, we examine the growth rate of the percentage of the population living under $\$ 1$ a day (and $\$ 2$ a day in robustness tests). By controlling for average per capita GDP growth, we test whether financial development exerts a positive, negative, or no influence on poverty beyond the impact of finance on average per capita GDP growth. Finally, we conduct the same experiment, but we use the growth rate of the Poverty Gap measure, which not only measures the percentage of the population living under $\$ 1$ a day, but also weighs this percentage by how far below $\$ 1$ a day incomes lie. Again, we assess the impact of financial development on poverty alleviation while controlling for average growth. 
We find that financial development alleviates poverty and reduces income inequality. Thus, the data indicate that financial development exerts a disproportionately positive influence on the poor. Since existing work finds that financial development accelerates aggregate growth, our findings suggest that financial development alleviates poverty both by boosting growth and by reducing income inequality.

More specifically, there are three key findings. First, even when controlling for real per capita GDP growth, financial development boosts the growth rate of the poorest quintile's income. This suggests that financial development reduces income inequality. Second, financial development induces a drop in the Gini coefficient measure of income inequality. Again, the negative relationship between financial development and the growth rate of the Gini coefficient holds when controlling for real per capita GDP growth. This result further emphasizes that financial development reduces income inequality beyond the relationship between finance and aggregate growth. Third, financial development reduces the fraction of the population living on less than $\$ 1$ a day (or \$2 a day) and financial development lowers the Poverty Gap. Again, the positive relationship between financial development and poverty alleviation holds even when controlling for average per capita GDP growth. Furthermore, these results hold when using instrumental variables to control for the endogenous determination of financial development and when conditioning on a large number of other country characteristics. In sum, using different datasets, we find that financial development lowers poverty and reduces income inequality by exerting a disproportionately positive impact on the poor.

This paper is related to a large public policy oriented literature on the relationship between inequality and economic growth. While “... the conventional textbook approach is that inequality is good for incentives and therefore good for growth” (Aghion et al, 1999, p. 1615), considerable work 
actually suggests that income inequality hurts growth. ${ }^{9}$ To explain this negative relationship between inequality and growth, many theoretical models assume financial market imperfections impede the efficient allocation of capital (e.g., Aghion and Bolton, 1997; Banerjee and Newman, 1993; Galor and Zeira, 1993). Taking the financial market frictions as given and ignoring incentive effects, these models suggest that public policies that redistribute income from the rich to the poor will alleviate the adverse growth effects of income inequality and therefore boost aggregate growth. Our paper instead highlights an alternative policy approach: Financial sector reforms that reduce market frictions will lower income inequality and boost growth without the potential incentive problems associated with policies that redistribute resources.

Our research also relates to work on how capital market imperfections influence child labor and schooling. Using household data from Peru, Jacoby (1994) finds that lack of access to credit perpetuates poverty because poor households reduce their kids' education. Jacoby and Skoufias (1997) show that households from Indian villages without access to credit markets tend to reduce their children’s schooling when they receive transitory shocks more than households with greater access to financial markets. Similarly, Dehejia and Gatti (2003) find that child labor rates are higher in countries with under-developed financial systems, while Beegle, et al. (2003) show that transitory income shocks lead to greater increases in child labor in countries with poorly functioning financial systems. We contribute to this research by examining the aggregate relationship between financial development and both poverty alleviation and income inequality.

While our results are robust to different specifications, our analyses face several limitations. First, we use cross-country regressions, so the results are subject to the usual criticisms of crosscountry studies (Levine and Zervos, 1993). Nonetheless, each methodology suffers from various

\footnotetext{
${ }^{9}$ See Alesina and Rodrik (1994), Perotti (1993, 1996), Person and Tabellini (1994), Clarke (1995), and Easterly (2002). Though, also see Banerjee and Duflo (2003), Barro (2000), Forbes (2000), and Lundberg and Squire (2003). For reviews of the literature, see Benabou (1996) and Aghion, Caroli, and Garcia-Penalosa (1999).
} 
shortcomings and these cross-country comparisons provide evidence on a crucial issue: poverty alleviation. Second, we use an aggregate index of financial development that equals credit issued by financial intermediaries to private firms as a share of GDP. This index does not measure the degree to which the population in general or the poor in particular access financial services. Nevertheless, in this initial study, it is crucial to ascertain whether a standard measure of financial development, which past studies find explains economic growth, also helps account for cross-country differences in poverty reduction rates and changes in income inequality. Third, income distribution and poverty are measured with error (Lundberg and Squire, 2003; Dollar and Kraay, 2002). However, unless this measurement error is correlated with financial development in a very particular manner, measurement error will bias the results against finding a relationship between financial development and changes in income inequality. Finally, although our results show the importance of financial intermediaries for the poor, they are silent on how to foster poverty-reducing financial development. ${ }^{10}$ Future work needs to examine the linkages between particular policies toward the financial sector and poverty alleviation.

The remainder of the paper is organized as follows. Section 2 presents the data and describes the methodology. Section 3 discusses the results and section 4 concludes.

\footnotetext{
${ }^{10}$ For instance, on bank supervision, see Barth, Caprio, and Levine, 2004, 2005; Demirguc-Kunt, Laeven, and Levine, 2004; and Caprio, Laeven, and Levine 2004).
} 


\section{Data, Summary Statistics, and Econometric Methodologies}

This section describes the variables, provides summary statistics and correlations, and discusses the econometric methodologies we use to assess the relationship between financial development, poverty alleviation, and changes in income distribution. Table 1 lists the main variables by country.

\section{A. Data: Financial Development}

To measure financial development, we would ideally like indicators of the degree to which the financial system ameliorates information and transactions costs and facilitates the mobilization and efficient allocation of capital. Specifically, we would like indicators of how well each financial system researches firms and identifies profitable projects, exerts corporate control, facilitates risk management, mobilizes savings, and eases transactions. Unfortunately, no such measures are available across countries. Consequently, we rely on a commonly used measure of financial development that existing work shows is robustly related to economic growth.

Private Credit equals the value of credit by financial intermediaries to the private sector divided by GDP. This measure excludes credits issued by the central bank and development banks. Furthermore, it excludes credit to the public sector, credit to state-owned enterprises, and cross claims of one group of intermediaries on another. Thus, Private Credit captures the amount of credit channeled from savers, through financial intermediaries, to private firms. Private Credit is a comparatively comprehensive measure of credit issuing intermediaries since it also includes the credits of financial intermediaries that are not considered deposit money banks. After controlling for endogeneity, Levine, Loayza and Beck (2000) and Beck, Levine, and Loayza (2000) show a robust positive relationship between Private Credit and the growth rate of GDP per capita. Data on Private 
Credit are from the updated version of the Financial Structure Database (Beck, Demirguc-Kunt and Levine, 2001). There is a wide variation in Private Credit, ranging from less than $5 \%$ in Ghana, Sierra Leone, and Uganda to more than $120 \%$ in Hong Kong, Japan, and the Netherlands using data over the period 1980 to 2000 . As we describe below, we sometimes use data averaged over the period 1960-1999, and sometimes we use data over the period 1980-2000 depending on the other variables and specification.

\section{B. Data: Changes in Income Distribution and Poverty Alleviation}

To assess the impact of financial development on the poor, we examine (i) the growth of the income of the poorest quintile in each economy, (ii) the growth of the Gini coefficient, (iii) the growth of the percentage of the population living on less than \$1 (and \$2) dollars per day, and (iv) changes in a poverty gap indicator, which not only measures the fraction of the population living below $\$ 1$ dollar per day, but also how far below this line incomes lie. The remainder of this subsection defines these dependent variables in more depth.

Income Growth of the Poor equals the annual growth rate of the average per capita income of the lowest income quintile, computed over the period 1960-1999 (Dollar and Kraay, 2002). More specifically, we calculate the annual growth rate of the per capita income of the lowest income quintile by taking the difference between the log of the average income per capita of those in the lowest income quintile for the last observation and the log of the average income per capita of those in the lowest income quintile for the first observation, and dividing this log difference by the number of years between the two observations. Income of the poorest quintile is computed in constant 1985 US dollars using PPP exchange rates. 
We use Income Growth of the Poor to assess how financial development influences the poorest segment of each economy. Income Growth of the Poor is not a direct measure of income distribution, nor is it a consistent measure of poverty across countries. The poorest quintile in a rich country could be quite affluent compared to the median person in a poor country. Nevertheless, since we also control for the growth rate of overall GDP per capita, examining Income Growth of the Poor allows us to assess whether financial development exerts a disproportionately large impact on the poorest quintile. Some countries enjoyed rates of Income Growth of the Poor above five percent per annum (Finland, Hong Kong, Japan, Korea, Norway, and Singapore). Others actually suffered negative rates of Income Growth of the Poor of worse than two percent per year (Panama, Sierra Leone, and Zambia).

Growth of Gini equals the annual growth rate of each country’s Gini coefficient, computed over the period 1960-1999. More specifically, the Gini coefficient is derived from the Lorenz curve, which plots the cumulative percentage of the population on the horizontal axis and the cumulative percentage of income on the vertical axis for each country. A 45-degree diagonal line on this graph depicts a situation where there is perfectly even income distribution, such that, for example, 20 percent of the population receives 20 percent of the income, and 50 percent of the population receives 50 percent of the income. To measure income inequality, the Gini coefficient equals the ratio of the area between the Lorenz curve and the 45-degree line divided by the area below the 45degree line. Since the Lorenz curve equals the 45-degree line when there is perfect income equality, the Gini coefficient equals zero when perfect equality holds. The Gini coefficient ranges between zero - perfect equality -and one, where larger values imply greater income inequality. ${ }^{11}$ We use the first and last observation from the Dollar and Kraay (2002) database and calculate the annual

\footnotetext{
${ }^{11}$ We confirm the conclusions using the standard deviation of the income shares, which is highly correlated with the Gini coefficient.
} 
growth rate by dividing the log difference of the last and the first observations by the number of years between the two observations.

For both Income Growth of the Poor and Growth of Gini, we require a minimum of 20 years difference between the first and last observation when computing growth rates. On average, there are 30 years between the first and last observation when computing growth rates, with a maximum of 40 years. ${ }^{12}$ This produces identical coverage for the two data series (Income Growth of the Poor and Growth of Gini) and yields a sample of 52 developing and developed countries. Critically, we match other data - e.g. Private Credit and GDP per capita growth and Private Credit - with the sample period covered by Growth of Gini (and Income Growth of the Poor) in regressions where Growth of Gini (or Income Growth of the Poor) is the dependent variable.

It is worthwhile comparing information on Income Growth of the Poor and Growth of Gini. From Table 1, note that in Egypt, Finland, France, and Norway, the Gini coefficient shrank at a rate of more than one percent per annum, while the Dominican Republic, Ecuador, and the United States saw the Gini coefficient grow at almost one percent per annum. Also, observe that Egypt, Finland, France, Japan, and Singapore, and Norway Hong Kong enjoyed rapid rates of Income Growth of the Poor. As stressed by Besley and Burgess (2003), countries may experience very rapid Income Growth of the Poor because of rapid declines in Gini coefficients (Egypt, Finland, France, and Norway) and countries may enjoy rapid Income Growth of the Poor because the economy is enjoying rapid overall growth (Japan, Singapore, and Hong Kong).

Next, we consider two measures of poverty intensification.

Growth of Headcount equals the growth rate in the percentage of the population living below $\$ 1$ dollar per day (or $\$ 2$ dollars per day). These data are based on household surveys (Chen

\footnotetext{
${ }^{12}$ We could not compute regression-based growth rates because many countries do not have data for every year and therefore lack sufficient observations.
} 
and Ravallion, 2001). We use data for 58 developing countries. To assess the robustness of our results, we use two alternative definitions of poverty: \$1 per day and \$2 per day. ${ }^{13}$ Using Purchasing Power Parity exchange rates, these two definitions of poverty are converted into local currency and we determine the fraction of the population living below each line. Then, we compute the annual log growth rate using the last and first available observations on the fraction of the population living below the $\$ 1$ and $\$ 2$ per day poverty lines respectively, divided by the number of years between the first and last observation. ${ }^{14}$

Growth of Poverty Gap equals the growth rate of the Poverty Gap, where the Poverty Gap is computed as a weighted measure of (i) the fraction of the population living on less than one dollar per day and (ii) how far below one dollar per day incomes lie. Specifically, the Poverty Gap is the mean shortfall from the poverty line, expressed as a percentage of the poverty line. Again, we define the poverty line as either $1 \$$ or $2 \$$ per day and convert this into local currency using PPP exchange rates. Thus, the Poverty Gap measures both the breadth and depth of poverty (Chen and Ravallion, 2001). Then, we compute the Growth of Poverty Gap as the log difference between last and first available observation on the Poverty Gap, divided by the number of years between the first and last observation.

There are greater data limitations regarding the direct measures of poverty intensification (Growth of Headcount and Growth of Poverty Gap) than for Income Growth of the Poor and Growth of Gini. The data on Headcount and Poverty Gap are only available for the 1980s and 1990s, and frequently only for the 1990s. Thus, we do not use a 20-year minimum and simply calculate the annualized growth rates of Headcount and Poverty Gap for the longest available time

\footnotetext{
${ }^{13}$ However, see Pritchett (2003) who proposes much higher poverty lines.

${ }^{14}$ These data are available at http://research.worldbank.org/PovcalNet/jsp/index.jsp.
} 
span. ${ }^{15}$ Using shorter time frames could magnify the influence of any outlier observations and make the results more sensitive to business cycle fluctuations or crises. Therefore, we assess the robustness of our results by (i) limiting the sample to countries for which the growth rate in Headcount and Poverty gap is calculated over at least five years and (ii) eliminating outliers.

Table 1 indicates that there is wide variation across countries in poverty alleviation rates over the last two decades. The share of population living on less than a dollar per day increased at an annual rate of 39\% in Poland between 1992 and 1998. Headcount decreased by an annual rate of 21\% in Jamaica between 1988 and 2000.

\section{Descriptive Statistics and Correlations}

Panel A of Table 2 presents descriptive statistics and Panels B and C present correlations for the 1960-99 and 1980-99 samples, respectively. Consistent with earlier work, financial development is positively and significantly correlated with GDP per capita growth. Private Credit is also positively and significantly correlated with the Income Growth of the Poor, but is not significantly correlated with Growth of Gini. The Table confirms the Dollar and Kraay (2002) result that the Income Growth of the Poor is closely correlated (0.81) with overall GDP per capita growth. Also, there is a significant, negative correlation (-0.49) between the Income Growth of the Poor and Growth of Gini, which can be partly explained by the very high correlation between the income share of the poorest income quintile and the Gini coefficient. There is not a significant correlation between GDP per capita growth and either Growth of Headcount or Growth of Poverty Gap. However, Private Credit is significantly and negatively correlated with both Growth of Headcount and Growth of Poverty Gap, indicating that countries with more developed financial systems

\footnotetext{
${ }^{15}$ Unlike in the income distribution regressions, we include poverty data of transition economies outside the Former Soviet Union after 1990. We do not include the countries of the Former Soviet Union due to data quality and availability.
} 
experienced a faster reduction in the number of people living in poverty. We also find a very high correlation (0.93) between Growth of Headcount and Growth of Poverty Gap.

\section{Econometric Methodologies: Basic Regression Specifications}

This subsection sketches the basic regression specifications used to examine the relationship between financial development and poverty alleviation and income inequality. Here, we simply describe ordinary least squares equations (OLS). The next subsection discusses how we deal with potential simultaneity bias. We use cross-country regressions, calculating growth rates of income, inequality and poverty over the longest available time period and averaging financial intermediary development and other explanatory variables over the corresponding time period. This approach differs from Dollar and Kraay (2002) and Lopez (2003) who use panel techniques. We focus on cross-country regressions for two reasons. First, we are assessing theories that focus on the longrun relationship between financial development and poverty alleviation, and therefore we want to abstract of business-cycle forces and crises that may influence banking systems and poverty in the short-run. Second, the poverty data in particular, but also the inequality data, are available for only a limited number of years and sometimes with gaps in the time-series. Since small samples can make the dynamic panel estimates unstable and unreliable as discussed in Beck and Levine (2004a), we examine the long-run relationship between financial development and (i) income growth of the poor, (ii) changes in income inequality, and (iii) rates of poverty alleviation. ${ }^{16}$

\section{D.1. Income Growth of the Poor}

To evaluate the impact of financial development on income growth of the poorest income

\footnotetext{
${ }^{16}$ Also, the GMM difference estimator used by Lopez (2003) abstracts from cross-country variation and only assesses time-series relationships.
} 
quintile, we use data averaged over the period 1960-99 and use the following regression specification.

$$
\left(y_{i, p, t}-y_{i, p, t-n}\right) / n=\alpha y_{i, p, t-n}+\beta F D_{i}+\gamma X_{i}+\varepsilon_{i},
$$

In this regression, $y_{i, p, t}$ is the logarithm of average per capita income of the poorest income quintile in country $i$ in year $t, y_{i, t}$ is the logarithm of average overall GDP per capita, $F D_{\mathrm{i}}$ is our Private Credit measure of financial development in country $\mathrm{i}$, and $X_{\mathrm{i}}$ is a set of conditioning information for country i. ${ }^{17}$ We control for the logarithm of the average years of school attainment in 1960 as an indicator of the initial human capital stock in the economy (Schooling 1960), the growth rate of the GDP deflator over the period 1960-99 to control for the macroeconomic environment (Inflation) and the sum of exports and imports as share of GDP to capture the degree of international openness (Trade Openness). As noted, the period of aggregation, n, is at least 20 years.

The coefficient $\beta$ in regression equation (1) captures the relationship between financial development and the growth rate of the average income of the poorest 20 percent of society. This regression set-up does not allow us to assess how much of the effect of Private Credit is due to its positive effect on overall GDP per capita growth and how much is due to distributional effects that influence the poorest income quintile relative to other income groups.

To better understand the distributional effect of financial development, we follow Dollar and Kraay (2002) and control for real GDP per capita growth in the regression. Specifically, we modify equation (1) by including average growth as a regressor.

$$
\left(y_{i, p, t}-y_{i, p, t-n}\right) / n=\alpha\left(y_{i, t}-y_{i, t-n}\right) / n+\beta F D_{i}+\gamma X_{i}+\lambda y_{i, p, t-n}+\varepsilon_{i},
$$

The coefficient $\alpha$ indicates the relationship between the growth rate of average per capita

\footnotetext{
${ }^{17}$ In line with the finance and growth literature (Levine, 2005), we include Private Credit in logs to control for nonlinearities in the relationship.
} 
income of the poor and overall per capita GDP growth. If the average income of the poorest quintile grows faster than average per capita GDP growth, $\alpha$ will be greater than one. If the income of the poorest quintile grows more slowly than average, $\alpha$ will be less than one.

The coefficient $\beta$ indicates whether there is any differential effect of financial development on income growth of the poorest quintile beyond any impact on overall GDP per capita growth. Thus, if financial development only boosts the income growth of the poor by increasing overall economic growth, then $\beta$ will equal zero. If financial development exerts a particularly positive impact on the rich, then $\beta$ will be negative. And, if financial development exerts a disproportionately positive impact on the poorest quintile, then $\beta$ will enter positively. ${ }^{18}$

\section{D.2. Growth of Gini}

To further assess the distributional effects of financial development, we examine Growth of

Gini:

$$
\left(G_{i, t}-G_{i, t-n}\right) / n=\alpha\left(y_{i, t}-y_{i, t-n}\right) / n+\beta F D_{i}+\gamma X_{i}+\lambda G_{i, t-n}+\varepsilon_{i},
$$

where $G_{i, t}$ is the $\log$ of the Gini coefficient in country $\mathrm{i}$ in period t. As before, the time period $n$ is at least 20 years. As in regression (2), we include the GDP per capita growth rate to (a) separate the distributional effect of Private Credit from the aggregate growth effect and (b) control for any effect that GDP per capita growth has on income distribution (Bourguignon, 2001b). If financial development does not affect the distribution of income, then $\beta$ will equal zero. If financial development reduces income inequality, then $\beta$ will be negative. And, if financial development exacerbates income inequality, then $\beta$ will enter positively.

\footnotetext{
${ }^{18}$ Unlike Dollar and Kraay (2002), we also include log of initial income of the poor to control for convergence forces. As shown, however, the findings hold when excluding initial income.
} 


\section{D.3. Growth of Headcount and Growth of Poverty Gap}

We also explore the impact of financial development on direct measures of poverty alleviation. To do this, we regress Growth of Headcount and Growth of Poverty Gap on financial development, while controlling for the overall growth rate of GDP per capita, and each country's initial poverty level.

$$
\left(P_{i, t}-P_{i, t-n}\right) / n=\alpha\left(y_{i, t}-y_{i, t-n}\right) / n+\beta F D_{i}+\gamma X_{i}+\lambda P_{i, t-n}+\varepsilon_{i}
$$

In this equation, $P_{i, t}$ is the log of Headcount or Poverty gap in country $\mathrm{i}$ in year $\mathrm{t}$.

Again, by controlling for GDP per capita growth, we identify the relationship between financial development and poverty alleviation conditional on aggregate economic growth. Thus, this equation also captures the distributional effect of Private Credit on poverty alleviation because we control for the effect of financial development on poverty that runs through overall economic growth. Since the sample periods vary significantly across countries, we match the sample period for GDP per capita growth with the period used to compute Growth of Headcount and Growth of Poverty Gap. We take the average of Private Credit over the period 1980 to 2000 to abstract from business cycle or crisis frequencies. ${ }^{19}$

\section{E. Econometric Methodologies: Instrumental Variables}

To control for potential reverse causation and simultaneity bias, we use instrumental variable (IV) regressions. The relationship between financial intermediary development and changes in income distribution and poverty might be driven by reverse causation. For example, reductions in poverty may stimulate demands for financial services. As another example,

\footnotetext{
${ }^{19}$ For the transition economies, we include Private Credit averaged over the period 1991 to 2000.
} 
reductions in income inequality might lead to political pressures to create more efficient financial systems that fund projects based on market criteria, not political connections.

To select instrumental variables for financial development, we focus on exogenous national characteristics that theory and past empirical work suggest influence financial development. We follow the finance and growth literature and use the legal origin of countries and the absolute value of the latitude of the capital city, normalized between zero and one, as instrumental variables. In particular, an extensive literature holds that British common law countries do a comparatively better job than French civil, German civil, Scandinavian civil, or Socialist law countries at protecting private property rights, fostering private contracting, and hence promoting financial development (See La Porta et al, 1997, 1998; and the review by Beck and Levine, 2004b). Furthermore, an extensive literature holds that natural resource endowments, which are imperfectly proxied by latitude, help explain the development of national institutions (Acemoglu, Johnson, and Robinson, 2001; Engerman and Sokoloff, 1997; and Easterly and Levine, 2003). Previous research demonstrates that both legal origin and latitude explain cross-country differences in financial development (Beck, Demirguc-Kunt and Levine, 2003). We also tried alternative instrument sets, including the religious composition of countries and ethnic fractionalization based on research by Stulz and Williamson (2003) and Easterly and Levine (1997) respectively, and obtained very similar results.

To test the appropriateness of the instruments, we use the Hansen test of the overidentifying restrictions, which assesses whether the instrumental variables are associated with the dependent variable beyond their ability to explain cross-country variation in Private Credit. Under the joint null hypothesis that the excluded instruments (i.e., the instruments not included in the second stage regression) are valid instruments, i.e., uncorrelated with the error term, and that the excluded 
instruments are correctly excluded from the estimated equation, the Hansen test is distributed $\chi^{2}$ in the number of overidentifying restrictions. Failure to reject the null hypothesis implies a failure to reject the validity of the instrumental variables. In the tables, we provide the p-values of this test of the overidentifying restrictions and refer to it as "OIR Test”. Furthermore, appropriate instruments must explain cross-country variation in financial development. In all the regressions reported below, we reject the null hypothesis that the exogenous variables do not explain cross-country variation in financial development.

\section{Empirical Results}

\section{A. Changes in Income Distribution}

\section{A.1. Income Growth of the Poor}

The Table 3 results indicate that (i) financial development increases the growth rate of the incomes of the poorest quintile and (ii) financial development exerts a disproportionately large positive impact on the poor since finance is positively related to growth even when controlling for the growth rate of average per capita GDP. These results are robust to controlling for various country characteristics and to using instrumental variables to mitigate simultaneity bias.

Consider first regression 1, where we conduct a preliminary analysis of the direct relationship between financial development and the growth rate of the incomes of the poor without controlling for average growth. This regression is very similar to standard cross-country growth regressions except that here the dependent variable is the per capita growth rate of the income of the poorest quintile. As in standard growth regressions, we condition on the logarithm of the initial level of income, which in this specification is the initial level of income of the poorest quintile in 1960 (Initial Income of the Poor). The regression indicates that the average income of the poorest 
quintile grows faster in countries with better-developed financial intermediaries. The log of initial average income of the poorest quintile enters significantly and negatively, suggesting conditional convergence of the poorest income quintile, i.e., the incomes of the poor grow faster in countries where the poor start out poorer. Since we are focusing on the income distributional consequences of financial development and its impact on poverty, we now turn to specifications where we control for average GDP per capita growth. Nonetheless, we note that (a) the regression 1 results are robust to controlling for Schooling in 1960, Inflation and Trade Openness and (b) the results hold when using instrument variables to extract the exogenous component of financial development.

Next, by controlling for average GDP per capita growth, we examine whether financial development benefits the poorest income quintile relatively more than the overall population (Table 3 , regression 2). Specifically, the results in regression 1 do not distinguish the impact of financial development on overall per capita GDP growth from the impact of finance on the distribution of income. Regression 2 separates the growth and distributional effects by regressing the growth rate of the average income of the poorest quintile on the overall GDP per capita growth rate, log of initial income of the poor and Private Credit. The coefficient on Private Credit thus captures the effect of financial development on the poorest income quintile beyond its overall growth effect.

There are two key results in regression 2: Financial development is particularly beneficial to the poor and the average income of the poor rises approximately one-for-one with overall economic growth. First, the positive and significant coefficient on Private Credit indicates that financial development disproportionately boosts the growth rate of the incomes of the poor. That is, financial development is positively associated with income growth of the poor beyond finance's effect on overall growth. GDP per capita growth enters positively and significantly in regression 2. Second, consistent with Dollar and Kraay (2002), we cannot reject at the $10 \%$ level that the coefficient on 
GDP per capita growth equals one, so that the average income of the poor increases proportionally with overall GDP per capita growth. In robustness tests, we confirm that these OLS results are robust to controlling for Inflation and Trade Openness. Finally, note in regression 3 of Table 3 that the results hold when excluding the logarithm of Initial Income of the Poor from the regression.

Figure 1 (i) displays the positive relationship between Private Credit and Income Growth of the Poor while controlling for GDP per capita growth and (ii) illustrates the potential importance of controlling for outliers. In particular, Figure 1 presents a partial scatter plot of Income Growth of the Poor against Private Credit and includes the estimated regression line. Using regression 2 of Table, which regresses Income Growth of the Poor against GDP per capita growth and Private Credit, this figure represents the two-dimensional representation of the regression plane in Income Growth of the Poor - Private Credit space. To obtain this figure, we regress Income Growth of the Poor on GDP per capita growth and Initial Income of the Poor, collect the residuals, and call them e(Income Growth of the Poor $\mid X)$. Next, we regress Private Credit against GDP per capita growth and Initial Income of the Poor, collect the residuals, and call them e( Private Credit $\mid X)$ ). Figure 1 plots e(Income Growth of the Poor $\mid \mathrm{X}$ ) against e( Private Credit $\mid \mathrm{X}$ ). Figure 1 suggests that outliers may exert an excessively large influence on the relationship between financial development and income growth of the poor. To assess the impact of outliers, therefore, we used the recommendations of Besley, Kuh, and Welsch (1980) for assessing the influence of individual observations. We (i) computed the change in the coefficient on Private Credit when the ith observation is omitted from the regression, (ii) scale the change by the estimated standard error of the coefficient, (iii) take the absolute value, and (iv) call the result $\Delta \beta_{\mathrm{i}}$. Then, we use the Belsley, Kuh, and Welsch recommendation of a critical value of two, and identify those observations where abs $\left(\Delta \beta_{\mathrm{i}}\right)>2$ /sqrt (n), where abs $(\mathrm{x})$ yields the absolute value of $\mathrm{x}$, $\operatorname{sqrt}(\mathrm{x})$ yields the square root of $\mathrm{x}$, 
and $\mathrm{n}$ represents the number of observations in the regression. When we do this and omit outlier countries (those countries where abs $\left(\Delta \beta_{\mathrm{i}}\right)>2$ /sqrt (n)), we obtain the same results. ${ }^{20}$ Indeed, omitting these "outliers” increases the t-statistics on Private Credit's estimated coefficient to above six without changing the coefficient estimate appreciably.

When using instrumental variables to control for the potential endogenous determination of financial development, we continue to find that financial development exerts a disproportionately positive impact on the growth rate of incomes of the poor. Regressions 4-7 use instrumental variables for financial development, control for average per capita GDP growth, and also condition on different country characteristics. ${ }^{21}$ Private Credit enters positively and significantly in all of the regressions, suggesting that financial development boosts the incomes of the poor above and beyond its affect on average growth. The control variables do not enter significantly. This does not suggest that Trade Openness, Schooling, and Inflation are unimportant for growth. Rather, this result suggests that Trade Openness, Schooling, and Inflation do not have income distribution effects when controlling for the level of financial development. Moreover, for this paper’s purposes, controlling for these country traits does not change the size or the significance of the coefficient on Private Credit. $^{22}$ In terms of assessing the validity of the instruments, the first-stage R-squares are all above 0.59 and we reject the hypothesis that the exogenous variables do not explain Private Credit. Moreover, we do not reject the test of the overidentifying restrictions in any of the regressions.

In robustness tests, we examined whether the relationship between financial development and income growth of the poor depends on the level of economic development or the level of

\footnotetext{
${ }^{20}$ The influential observations that are omitted are Sierra Leone, Panama, Sri Lanka, and Turkey. Figure 1 indicates that Sierra Leone is a particularly large outlier. The results hold even when we only exclude Sierra Leone.

${ }^{21}$ We present only IV regressions, but the OLS regressions yield the same findings.

${ }^{22}$ Furthermore, controlling for measures of fiscal policy does not change the results on Private Credit.
} 
educational attainment based on insights by Greenwood and Jovanovic (1990) and Galor and Moav (2005). Besides including the level of educational attainment, we added the level of GDP per capita to the Table 3 regressions. We added GDP per capita both when including and excluding the level of education. In these specifications, the data continued to indicate that finance exerts a disproportionately positive effect on the poor even when controlling both economic growth and the level of economic development. Furthermore, we included (i) the interaction term of financial development and the level of economic development and (ii) the interaction term of financial development and educational attainment. These interaction terms do not enter significantly. Thus, we found no evidence that the relationship between financial development and income growth of the poor varies with the level of GDP per capita or the level of educational attainment.

The distributional effect of Private Credit is not only statistically significant but also economically relevant. First, note that the coefficient on Private Credit in regression 1, which does not control for GDP per capita growth, is 0.031, while the coefficient on Private Credit in the same specification that controls for GDP per capita growth is 0.017 (regression 2). These coefficients suggest that about half of the overall effect of Private Credit on the income growth of the poorest quintile does not occur through the impact of financial development on average growth. Next, consider the case of Brazil. The instrumental variable results in Table 3 regression 2 indicate that average income of the poor in Brazil would have grown at more than 1.5\% instead of $0 \%$ annually over the period 1960-99 if Brazil (Private Credit = 28\%) had the same level of financial intermediary development as Korea (74\%). ${ }^{23}$ This suggests an economically large impact of financial development on income growth of the poor given that Brazil’s GDP per capita grew at 2\%

\footnotetext{
${ }^{23}$ To get this, recall that the regressors are in logs and note that the $\ln (0.740)-\ln (0.276)=0.99$. Multiplying this with the coefficient in column 2 (0.016) suggests that growth would be more than $1.5 \%$ faster. Note this is only an illustrative example. Such conceptual experiments do not explain how to improve financial development and the changes discussed above are not marginal.
} 
over the same period.

\section{A.2.: Growth of Gini}

In Table 4, we use the growth rate of the Gini coefficient measures of income distribution to assess the distributional consequences of financial development. The dependent variable is the annual growth rate in the Gini coefficient over the period 1960 - 99. Since the Gini coefficient is a direct measure of income distribution, we do not use the standard growth equation framework (as in regression 1 of Table 3). Rather, we focus on the income distribution consequences of financial and use specifications that include GDP per capita growth, the initial level of the Gini coefficient in 1960 (Initial Gini), and also control for different country traits. ${ }^{24}$ Regression 1 presents simple OLS results and the other regressions use two stage least squares and different control variables. In sensitivity checks, we confirm that the OLS results hold when using these different control variables.

The results indicate that financial development reduces income inequality. Private Credit enters negatively and significantly in all of the specifications. When controlling for Initial Gini, GDP per capita growth, Schooling 1960, the macroeconomic and international environments (Inflation and Trade Openness), and when using, or not using, instrumental variables to extract the exogenous component of Private Credit, there is a negative relationship between financial development and Growth of Gini. In the IV regressions, the OIR is not rejected and the instrumental variables (legal origins and latitude) jointly explain financial development in all the regressions. In terms of the other variables, Initial Gini enters negatively, suggesting that countries with initially highly unequal income profiles (high Initial Gini) tend to see faster reductions in income inequality holding other things constant. Also, the IV regressions suggest that GDP per capita growth is

\footnotetext{
${ }^{24}$ We also tested for non-linearities by including the squared term of Private Credit, but it never entered significantly.
} 
associated with increases in income inequality when conditioning on financial development. This may create concerns that financial development intensifies income inequality by boosting growth, while exerting a negative direct effect on income inequality. On net, however, financial development reduces income inequality. We continue to find a negative and significant coefficient on Private Credit when we omit GDP per capita growth from the regression or when we omit Initial Gini. Thus, the negative impact of financial development on income inequality does not depend on conditioning on either GDP per capita growth or Initial Gini.

Figure 2 provides the partial scatter plot of the Growth of Gini against Private Credit and again suggests that possible role of outliers. We use the same methodology to construct Figure 2 as we used to construct Figure 1. While there is clearly substantial variability, the figure illustrates a strong negative relationship between financial development and the growth rate of income inequality. Furthermore, we use the same methodology to remove observations that may exert an exceptionally large impact on the slope of the regression line. Thus, following, Besley, Kuh, and Welsch (1980) we omit those countries where abs $\left(\Delta \beta_{\mathrm{i}}\right)>2 /$ sqrt $\left.(n)\right) .{ }^{25}$ Omitting these “outliers” actually strengthens the relationship between financial development and the growth rate of the Gini coefficient, i.e., both the absolute value of the estimated coefficient Private Credit and its t-statistic increase. Thus, outliers do not seem to drive the negative association between finance and changes in income inequality.

In sum, the results in Tables 3 and 4 indicate that financial intermediary development exerts a disproportionately positive impact on the poor and reduces income inequality. Private Credit raises the incomes of the lowest income quintile beyond the overall income growth rate of incomes in the economy. Moreover, Private Credit reduces income inequality, as measured by the Gini

\footnotetext{
25 The influential observations that are omitted are Sierra Leone, Panama, Sri Lanka, the United States, and Finland.
} 
coefficient, when controlling for the initial level of income inequality in the economy and average growth. Both results hold when using two-stage least squares to control for simultaneity bias.

\section{B. Poverty Alleviation}

Next, we examine the relationship between financial development and measures of poverty alleviation. This has the advantage of directly assessing the focus of our investigation: poverty alleviation. The disadvantage is that the data cover far fewer years. For the Income Growth of the Poor and Growth of Gini analyses, we examined growth rates computed over an average of 30 years, with a minimum of 20 and a maximum of 40 years. Thus, we were testing the impact of finance on long-run growth rates of incomes of the poor and Gini coefficients. Now, we directly examine poverty alleviation, but the growth rates are sometimes computed for less than five years and frequently for less than 10 years. This reduces confidence that these poverty alleviation results capture the relationship between financial development and reductions in poverty over long periods.

To address concerns about limited time-series data on poverty, we do three things. First, we control for GDP per capita growth. Besides isolating the relationship between financial development and poverty alleviation beyond the relationship between finance and aggregate growth, including GDP per capita growth controls for higher frequency economic fluctuations and therefore provides some comfort that we assessing the long-run relationship between financial development and poverty alleviation. Second, we confirm the Table 5 results when limiting the sample to only those countries where we have a minimum of five years of data. Finally, we control for the logarithm of the initial values of Headcount and the Poverty Gap, respectively, and also condition on the general macroeconomic and international environment (Inflation and Trade 
Openness). ${ }^{26}$ Besides providing general sensitivity checks, controlling for these country characteristics increases confidence that we are identifying the long-run relationship between financial development and poverty alleviation and not convergence effects or changes in the macroeconomic or international environment that induce a spurious correlation between finance and poverty alleviation.

Financial development reduces the growth rate of the two poverty indicators: Growth of Headcount and Growth of Poverty Gap (Table 5). Private Credit enters negatively and significantly in the OLS regressions (regressions 1 and 2). Private Credit also enters negatively and significantly in all of the instrumental variables with different control variables, except in the Growth of Poverty Gap regression when we control for Schooling 1980 (regressions 3-10). In the IV regressions, the specification tests suggest that the instruments are valid. The test of overidentifying restrictions is not rejected and the instruments jointly explain cross-country variation in Private Credit.

Figure 3 is a partial scatter plot of the Growth of Headcount against Private Credit, which both illustrates the strong negative relationship between financial development and changes in poverty and suggests the potential influence of outliers. We use the same methodology to construct Figure 3 that we describe above in relation to Figures 1 and 2. Figure 3 clearly illustrates that greater financial development is associated with poverty alleviation. Next, we use the Besley, Kuh, and Welsch (1980) methodology for identifying and removing observations that exert an exceptionally large impact on the slope of the regression line. As described in detail above, we omit those countries where abs $\left.\left(\Delta \beta_{\mathrm{i}}\right)>2 / \mathrm{sqrt}(\mathrm{n})\right) .{ }^{27}$ Omitting these "outliers" does not change the estimated coefficient on Private Credit or its t-statistic. Thus, outliers are not producing the negative association between finance and changes in poverty.

\footnotetext{
${ }^{26}$ As noted above, these results hold when controlling for differences in fiscal policy across countries.

27 The influential observations that are omitted are Uganda, Ghana, Laos, and Poland.
} 
The effect of Private Credit on poverty alleviation is not only statistically but also economically substantial. Compare Chile (Private Credit $=54 \%)$ with Peru $($ Private Credit $=13 \%)$. In Chile, the percentage of the population living on less than $\$ 1$ a day (Headcount) decreased at an annual growth rate of 14\% between 1987 and 2000. In Peru, the Headcount increased at an annual growth rate of $19 \%$ over the period 1985 to 2000 . The OLS results in column 1 indicate that if Peru had had Chile's level of financial intermediary development, Headcount would have increased only at an annual rate of 5\% per year, which would have resulted in a share of the population living on less than one dollar of about $2 \%$ in 2000 rather than the actual value of $15 \% .{ }^{28}$ Thus, the economic impact of financial development on the poverty is quite large. The IV results provide an even stronger assessment of the economic impact of well-developed financial intermediaries.

While we have stressed the robustness of the results to various permutations throughout the presentation, we emphasize two additional sensitivity tests in closing. First, there may exist concerns that we have not controlled for the level of real per capita GDP in the poverty alleviation regressions. Instead, we control for the initial level of the poverty indicators in Table 5. Nevertheless, when we control for the initial level of real per capita GDP, none of the results changes. Second, selecting a poverty line is inherently arbitrary. Thus, we re-did the analyses of poverty alleviation using the $\$ 2$ a day poverty line. We confirm the Table 5 results: Financial development reduces the fraction of the population living below $\$ 2$ a day.

\footnotetext{
${ }^{28}$ To get this, recall that the regressors are in logs and note that the $\ln (0.54)-\ln (0.13)=1.42$. Multiplying this with the coefficient in column $1(-0.1)$, yields 0.14 . Thus, instead of growing at a rate of 0.19 , Peru's Headcount would have grown at an annual rate of 0.05 . Starting from an initial value of Headcount of 1.1 percent and accumulating over 15 years, yields the result in the text.
} 


\section{Conclusions}

An extensive literature shows that financial development is positively associated with the growth rate of per capita GDP. This does not necessarily mean, however, that financial development reduces poverty. If financial development increases average growth only by increasing the incomes of the rich and hence by increasing income inequality, then financial development will not lower poverty rates.

Given the extremely high rates of poverty around the world, this paper focuses on whether financial development reduces poverty. Because of measurement problems, we assess the impact of financial development on poverty alleviation in two ways. First, we assess the relationship between financial development and changes in the distribution of income. Here, we use data on 52 developing and developed economies with data averaged over the period 1960 to 1999 . Second, we assess the direct relationship between financial development and poverty alleviation. Here, we use data on 58 developing countries with data over the period 1980 to 2000.

This paper finds that greater financial development induces (i) incomes of the poor to grow faster than average GDP per capita, (ii) income inequality to fall more rapidly, and (iii) poverty rates to decrease at a faster rate. All of these results hold when controlling for the average rate of economic growth, which suggests that financial development alleviates poverty beyond its affect on aggregate growth. Furthermore, these results hold when using instrumental variables to control for endogeneity bias. Thus, we find that financial development reduces poverty by exerting a disproportionately positive effect on the poor. Future research needs to identify which policies induce poverty-alleviating improvements in the financial system. 


\section{REFERENCES}

Acemoglu, Daron, Simon Johnson, and James Robinson, 2001. The Colonial Origins of Comparative Development: An Empirical Investigation. American Economic Review 91, 1369-1401.

Aghion, Philippe and Patrick Bolton, (1997). A Trickle-Down Theory of Growth and Development with Debt Overhang, Review of Economic Studies 64, 151-72.

Aghion, Philippe, Caroli, Eve, and Cecilia Garcia-Penalosa (1999). Inequality and Economic Growth: The Perspective of the New Growth Theories, Journal of Economic Literature 37, 16151660 .

Aghion, Philippe and Peter Howitt (1998) Endogenous Growth Theory. Cambridge: MIT Press.

Aghion, Philippe, Peter Howitt, and David Mayer-Foulkes (2005), The Effect of Financial Development on Convergence: Theory and Evidence, Quarterly Journal of Economics, forthcoming.

Alesina, Alberto and Dani Rodrik (1994): Distributive Politics and Economic Growth, Quarterly Journal of Economics 109, 465-90.

Banerjee, Abhijit V. and Esther Duflo (2003): Inequality and Growth: What Can the Data Say? MIT mimeo, June.

Banerjee, Abhijit and Newman, Andrew (1993): Occupational Choice and the Process of Development, Journal of Political Economy 101, 274-98.

Barro Robert J. (2000): Inequality and Growth in a Panel of Countries, Journal of Economic Growth, 5, 5-32.

Barro, Robert J. and Jong-Wha Lee (1993), International Data on Education Attainment: Updates and Implications, Oxford Economic Papers, 2001. (Updated data are available from: http://worldbank.org/research/growth/ddbarlee.htm)

Barth, James R., Gerard Caprio, Jr., and Ross Levine (2004): Bank Supervision and Regulation: What Works Best? Journal of Financial Intermediation 13, 205-48.

Barth, James R., Gerard Caprio, Jr., and Ross Levine (2005). Rethinking Bank Supervision and Regulation: Until Angels Govern. Cambridge, UK: Cambridge University Press, forthcoming.

Beck, Thorsten, and Ross Levine (2004a): Stock Markets, Banks and Growth: Panel Evidence, Journal of Banking and Finance 28, 423-442.

Beck, Thorsten, and Ross Levine (2004b). Legal Institutions and Financial Development. In Claude Menard and Mary Shirley, Eds., Handbook of New Institutional Economics. The Netherlands: Springer Press, forthcoming. 
Beck, Thorsten, Ross Levine, and Norman Loayza, (2000): Finance and the Sources of Growth. Journal of Financial Economic 58, 261-300.

Beck, Thorsten, Asli Demirgüç-Kunt, and Ross Levine, (2001): The financial structure database. In Demirguc-Kunt, A., Levine, R. (Eds.), Financial Structure and Economic Growth: A CrossCountry Comparison of Banks, Markets, and Development. MIT Press, Cambridge, MA, pp. 1780 .

Beck, Thorsten; Asli Demirguc-Kunt, and Ross Levine, (2003): Law, Endowments and Finance, Journal of Financial Economics 70, 137-81.

Beegle, Kathleen, Rajeev H. Dehejia, and Roberta Gatti, (2003): Child Labor, Crop Shocks, and Credit Constraints, National Bureau of Economic Research Working Paper, 10088.

Benabou, Roland (1996): Inequality and Growth, NBER Macroeconomic Annual, 11, 11-74.

Besley, Kuh and Welsch, 1980. Regression Diagnostics: Identifying Influential Data and Sources of Collinearity. New York: Wiley

Besley, Timothy and Robin Burgess, (2003): Halving Global Poverty, Journal of Economic Perspectives 17, 3-22.

Bourguignon, Francois (2001a): Pareto-Superiority of Unegalitarian Equilibria in Stiglitz's Model of Wealth Distribution with Convex Savings Function, Econometrica 49, 1469-75.

Bourguignon, Francois (2001b): The Pace of Economic Growth and Poverty Reduction, Paper presented at LACEA 2001 Conference.

Bourguignon, Francois (2004): The Poverty-Growth-Inequality Triangle. World Bank mimeo.

Bourguignon, François and Thierry Verdier (2000): Oligarchy, democracy, inequality and growth, Journal of Development Economics (62)2, 285-313

Caprio, Gerry; Luc Laeven and Ross Levine (2004): Governance and Bank Valuation, World Bank Policy Research Working Paper, \#3202.

Chen and Ravillion, 2001” How Did the World's Poor Fare in the 1990s? Review of Income and Wealth 47, 283-300.

Clarke, George (1995): More evidence on income distribution and growth,” Journal of Development Economics Vol. 47, 403-427.

Clarke, George; Lixin Colin Xu and Heng-fu Zou (2003): Finance and Income Inequality, Test of Alternative Theories, World Bank Policy Research Working Paper, \#2984.

Dehejia, Rajeev H. and Roberta Gatti, (2003): Child Labor: The Role of Income Variability and Credit Constraints Across Countries, World Bank mimeo 
Demirgüç-Kunt, Aslı, Luc Laeven, and Ross Levine. (2004): Regulations, Market Structure, Institutions, and the Cost of Financial Intermediation. Journal of Money, Credit, and Banking 36, 593-622.

Dollar, David and Aart Kraay (2002): Growth is Good for the Poor, Journal of Economic Growth 7, 195-225.

Easterly, William (2002): Inequality Does Cause Underdevelopment, Center for Global Development Working Paper, 1.

Easterly, William and Ross Levine (1997), Africa’s Growth Tragedy: Policies and Ethnic Division, Quarterly Journal of Economics, 112: 1203-1250.

Easterly, William and Ross Levine (2003), Tropics, Germs, and Crops: How Endowments Influence Economic Development, Journal of Monetary Economics, 50: 3-39.

Engerman, Stanley L. and Kenneth L Sokoloff, 1997. Factor Endowments, Institutions, and Differential Paths of Growth among New World Economies, in How Latin America Fell Behind. Stephen Haber, ed. Stanford, CA: Stanford University Press, pp. 260-304.

Fernandez, R. and R. Rogerson (1996): Income Distribution, Communities, and the Quality of Public Education, Quarterly Journal of Economic 111, 135-164.

Forbes, Kristin (2000): A Reassessment of the Relationship between Inequality and Growth, American Economic Review, 90, 869-887.

Galor, Oded and J. Zeira. (1993): Income Distribution and Macroeconomics. Review of Economic Studies 60, 35-52.

Galor, Oded and Omer Moav (2005): From Physical to Human Capital Accumulation: Inequality and the Process of Development. Review of Economic Studies, forthcoming.

Greenwood, Jeremy and Jovanovic, Boyan (1990): Financial Development, Growth, and the Distribution of Income, Journal of Political Economy 98, 1076-1107.

Haber, Stephen. H., Armando Razo, and Noel Maurer (2003), The Politics of Property Rights: Political Instability, Credible Commitments, and Economic Growth in Mexico, Cambridge University Press.

Honohan, Patrick (2004a): Financial Development, Growth and Poverty: How Close are the Links, in Charles Goodhart (ed.): Financial Development and Economic Growth: Explaining the Links, (London: Palgrave), forthcoming.

Jacoby, Hanan G. (1994): Borrowing Constraints and Progress Through School: Evidence from Peru, Review of Economics and Statistics 76, 151-60.

Jacoby, Hanan G. and Emmanuel Skoufias (1997): Risk, Financial Markets, and Human Capital, 
Review of Economic Studies 64, 311-335.

Kraay, Aart (2004): When is Growth Pro-Poor: Evidence form a Panel of Countries, World Bank mimeo.

La Porta, Rafael, Florencio Lopez-de-Silanes, Andrei Shleifer, and Robert W. Vishny. 1997. Legal Determinants of External Finance. Journal of Finance 52, 1131-1150.

La Porta, Rafael, Florencio Lopez-de-Silanes, Andrei, Shleifer, and Robert W. Vishny, (1997): Legal Determinants of External Finance, Journal of Finance, 52, 1131-1150.

Levine, Ross (1997), "Financial Development and Economic Growth: Views and Agenda”, Journal of Economic Literature, 35: 688-726.

Levine, Ross (2005): Finance and Growth: Theory and Evidence. In Handbook of Economic Growth, Eds. Philippe Aghion and Steven Durlauf, Amsterdam: North-Holland Elsevier Publishers, forthcoming.

Levine, Ross, Norman Loayza, and Thorsten Beck, (2000): Financial Intermediation and Growth: Causality and Causes. Journal of Monetary Economics 46, 31-77.

Levine, Ross, and Sara Zervos. (1993): What We Have Learned About Policy and Growth From Cross-Country Regressions. American Economic Review 83, 426-430.

Lopez, Humberto (2003): Pro-Growth, Pro-Poor: Is there a Tradeoff? World Bank mimeo.

Lundberg, Mattias and Lyn Squire, (2003): The Simultaneous Evolution of Growth and Inequality. Economic Journal 113, 326-44.

Mookherjee, D. and D. Ray (2003): Persistent Inequality. Review of Economic Studies 70, 369393.

Perotti, Roberto (1993): Political Equilibrium, Income Distribution, and Growth, Review of Economic Studies 60, 755-76.

Perotti, Roberto (1996): Growth, Income Distribution, and Growth, Journal of Economic Growth $1,149-87$

Person, Torsten and Guido Tabellini (1994): Is Inequality Harmful for Growth? American Economic Review 84, 600-21.

Pritchett, Lant (2003): Who is Not Poor? Proposing a Higher International Standard for Poverty, Harvard University mimeo.

Rajan, Raghuram and Luigi Zingales, (2003): Saving Capitalism from the Capitalists:

Unleashing the Power of Financial Markets to Create Wealth and Spread Opportunity. New York: Crown Business. 
Ravallion, Martin (2001): Growth, Inequality and Poverty: Looking Beyond Averages, World Development 29, 1803-15.

Stulz, Rene M. and Rohan Williamson (2003), Culture, Openness, and Finance, Journal of Financial Economics, 70, 313-349. 
GDP per capita is in constant 1995 US\$ and averaged over the period 1960-1999. Private Credit equals claims of financial institutions on the private sector as a share of GDP averaged over the period 1960-1999. Income Growth of the Poor equals the annual growth rate of income per capita of the poorest quintile over the period 1960-1999.Growth of Gini is the annual growth rate of the Gini coefficient over the period 19802000. Growth of Headcount is the annual growth rate of the percentage of the population living below the national poverty line, as defined as living on $\$ 1$ a day. Growth of Poverty Gap is the annual growth rate of the mean shortfall from the poverty line expressed as a percentage of the poverty line. Detailed variable definitions and sources are in the appendix.

\begin{tabular}{|c|c|c|c|c|c|c|}
\hline & GDP per capita & Private Credit & $\begin{array}{c}\text { Income Growth of } \\
\text { the Poor }\end{array}$ & Growth of Gini & $\begin{array}{l}\text { Growth of } \\
\text { Headcount }\end{array}$ & $\begin{array}{c}\text { Growth of Poverty } \\
\text { Gap }\end{array}$ \\
\hline Australia & 19,045 & 0.535 & 0.020 & 0.004 & & \\
\hline Burundi & 181 & 0.095 & & & 0.031 & 0.083 \\
\hline Burkina Faso & 241 & 0.134 & & & -0.084 & -0.161 \\
\hline Bangladesh & 291 & 0.202 & 0.015 & 0.002 & 0.019 & 0.018 \\
\hline Bulgaria & 1,536 & 0.089 & & & 0.296 & 0.170 \\
\hline Bahamas, The & 13,057 & 0.473 & 0.018 & -0.008 & & \\
\hline Bolivia & 887 & 0.288 & 0.010 & -0.005 & 0.109 & 0.230 \\
\hline Brazil & 4,217 & 0.273 & 0.003 & 0.007 & -0.018 & -0.018 \\
\hline Botswana & 2,751 & 0.116 & & & -0.010 & 0.002 \\
\hline Canada & 18,947 & 0.744 & 0.020 & 0.004 & & \\
\hline Chile & 3,621 & 0.538 & 0.011 & 0.005 & -0.143 & -0.133 \\
\hline Cote d'Ivoire & 916 & 0.310 & & & 0.092 & 0.144 \\
\hline Cameroon & 761 & 0.190 & & & -0.128 & -0.159 \\
\hline Colombia & 2,122 & 0.284 & 0.021 & 0.000 & 0.002 & -0.015 \\
\hline Costa Rica & 3,126 & 0.160 & -0.001 & 0.001 & -0.105 & -0.115 \\
\hline Germany & 27,272 & 0.966 & 0.018 & 0.000 & & \\
\hline Denmark & 32,113 & 0.413 & 0.027 & 0.002 & & \\
\hline Dominican Republic & 1,590 & 0.258 & -0.002 & 0.009 & & \\
\hline Algeria & 1,636 & 0.311 & & & -0.059 & -0.140 \\
\hline Ecuador & 1,746 & 0.233 & 0.003 & 0.011 & 0.209 & 0.263 \\
\hline Egypt, Arab Rep. & 958 & 0.325 & 0.042 & -0.010 & -0.028 & -0.026 \\
\hline Spain & 13,514 & 0.783 & 0.032 & -0.004 & & \\
\hline Ethiopia & 107 & 0.162 & & & -0.019 & -0.025 \\
\hline Finland & 25,114 & 0.628 & 0.057 & -0.018 & & \\
\hline France & 25,210 & 0.891 & 0.044 & -0.010 & & \\
\hline United Kingdom & 17,732 & 0.856 & 0.014 & 0.008 & & \\
\hline Ghana & 352 & 0.034 & & & -0.003 & 0.006 \\
\hline Gambia & 366 & 0.159 & & & -0.118 & -0.163 \\
\hline Greece & 11,057 & 0.398 & 0.022 & 0.003 & & \\
\hline Guatemala & 1,434 & 0.160 & & & -0.083 & -0.122 \\
\hline Guyana & 757 & 0.336 & -0.001 & -0.006 & -0.183 & -0.214 \\
\hline Hong Kong, China & 18,691 & 1.483 & 0.052 & 0.005 & & \\
\hline Honduras & 699 & 0.297 & 0.013 & -0.003 & -0.037 & -0.047 \\
\hline Croatia & 4,430 & 0.323 & & & 0.045 & -0.112 \\
\hline Hungary & 4,622 & 0.286 & & & 0.139 & 0.139 \\
\hline Indonesia & 794 & 0.300 & 0.044 & -0.002 & -0.088 & -0.127 \\
\hline India & 327 & 0.251 & 0.022 & -0.004 & & \\
\hline Jamaica & 1,970 & 0.266 & 0.015 & -0.007 & -0.209 & -0.261 \\
\hline Japan & 37,559 & 1.475 & 0.055 & -0.007 & & \\
\hline Kenya & 338 & 0.306 & & & -0.084 & -0.168 \\
\hline Korea, Rep. & 8,093 & 0.861 & 0.066 & 0.001 & & \\
\hline Lao PDR & 345 & 0.060 & & & 0.235 & 0.354 \\
\hline Sri Lanka & 646 & 0.190 & 0.034 & -0.005 & -0.033 & -0.048 \\
\hline Lesotho & 490 & 0.151 & & & 0.022 & 0.048 \\
\hline Morocco & 1,258 & 0.307 & & & -0.092 & -0.155 \\
\hline Madagascar & 265 & 0.147 & -0.017 & -0.002 & 0.010 & 0.016 \\
\hline
\end{tabular}




\begin{tabular}{|c|c|c|c|c|c|c|}
\hline & GDP per capita & Private Credit & $\begin{array}{c}\text { Income Growth of } \\
\text { the Poor }\end{array}$ & Growth of Gini & $\begin{array}{l}\text { Growth of } \\
\text { Headcount }\end{array}$ & $\begin{array}{c}\text { Growth of Poverty } \\
\text { Gap }\end{array}$ \\
\hline Mexico & 3,298 & 0.172 & 0.012 & 0.002 & -0.022 & 0.006 \\
\hline Mali & 264 & 0.131 & & & 0.296 & 0.451 \\
\hline Mongolia & 430 & 0.089 & & & 0.221 & 0.324 \\
\hline Mauritania & 446 & 0.315 & & & -0.045 & -0.078 \\
\hline Malaysia & 3,386 & 0.894 & 0.041 & 0.002 & -0.188 & -0.230 \\
\hline Niger & 242 & 0.120 & -0.013 & 0.007 & 0.124 & 0.334 \\
\hline Nigeria & 251 & 0.139 & -0.005 & 0.003 & 0.006 & 0.015 \\
\hline Nicaragua & 512 & 0.276 & & & 0.006 & 0.013 \\
\hline Netherlands & 24,810 & 1.215 & 0.035 & -0.009 & & \\
\hline Norway & 30,246 & 0.814 & 0.052 & -0.012 & & \\
\hline Pakistan & 436 & 0.237 & 0.028 & 0.000 & -0.114 & -0.160 \\
\hline Panama & 2,910 & 0.559 & -0.023 & 0.010 & & \\
\hline Peru & 2,278 & 0.135 & 0.001 & -0.006 & 0.191 & 0.238 \\
\hline Philippines & 1,095 & 0.333 & 0.016 & 0.004 & -0.026 & -0.039 \\
\hline Poland & 2,953 & 0.155 & & & 0.389 & 0.570 \\
\hline Portugal & 9,582 & 0.721 & 0.039 & -0.006 & & \\
\hline Paraguay & 1,832 & 0.182 & & & 0.123 & 0.231 \\
\hline Romania & 1,658 & 0.079 & & & 0.230 & 0.118 \\
\hline Senegal & 562 & 0.276 & -0.005 & 0.002 & -0.177 & -0.314 \\
\hline Singapore & 18,526 & 0.974 & 0.052 & 0.002 & & \\
\hline Sierra Leone & 273 & 0.036 & -0.077 & 0.006 & & \\
\hline El Salvador & 1,495 & 0.058 & -0.012 & 0.001 & 0.034 & 0.013 \\
\hline Slovenia & 10,091 & 0.258 & & & -0.139 & -0.139 \\
\hline Sweden & 27,103 & 1.078 & 0.033 & -0.009 & & \\
\hline Thailand & 2,009 & 0.711 & 0.031 & 0.004 & -0.127 & -0.246 \\
\hline Trinidad and Tobago & 4,502 & 0.436 & 0.021 & 0.002 & 0.141 & 0.400 \\
\hline Tunisia & 1,910 & 0.587 & 0.036 & -0.002 & -0.110 & -0.105 \\
\hline Turkey & 2,519 & 0.155 & 0.029 & -0.002 & -0.041 & -0.041 \\
\hline Uganda & 259 & 0.025 & & & -0.003 & -0.014 \\
\hline Uruguay & 5,512 & 0.317 & & & -0.056 & -0.048 \\
\hline United States & 25,730 & 0.944 & 0.011 & 0.009 & & \\
\hline Venezuela & 3,533 & 0.321 & 0.001 & 0.003 & 0.038 & 0.089 \\
\hline Vietnam & 253 & 0.150 & & & 0.039 & 0.054 \\
\hline South Africa & 4,137 & 0.521 & & & 0.010 & 0.029 \\
\hline Zambia & 478 & 0.062 & -0.027 & 0.004 & -0.002 & -0.025 \\
\hline
\end{tabular}


Panel A presents the descriptive statistics and Panels B and C present the correlations.

Income Growth of the Poor equals the annual change in the logarithm of the level of income per capita of the poorest quintile over the period 1960-1999. Growth of Gini is the annual change in the logarithm of the Gini coefficient over the period 1960-99. GDP Per capita growth equals the growth rate of real GDP per capita over the periods 1960-99 and 1980-00 respectively. Private Credit equals claims of financial institutions on the private sector as a share of GDP averaged over the periods 1960-99 and 1980-00 respectively. Growth of Headcount is the annual growth rate of the percentage of the population living below the national poverty line, as defined as living on $\$ 1$ a day, over the period $1980-2000$.

Growth of Poverty Gap is the annual growth rate of the mean shortfall from the poverty line expressed as a percentage of the poverty line, over the period 1980-2000. Panel B presents correlations for the period 1960-99. Panel C presents correlations for the sample 1980 - 2000. Detailed variable definitions and sources are in the appendix.

Panel A:

\begin{tabular}{lccrrr}
\hline Variable & Obs & \multicolumn{2}{c}{ Mean } & \multicolumn{1}{c}{ Std. Dev. } & \multicolumn{2}{c}{ Min } & Max \\
\hline Income growth of poor & 52 & 0.018 & 0.025 & -0.077 & 0.066 \\
Growth of Gini & 52 & 0.000 & 0.006 & -0.018 & 0.011 \\
GDP per capita growth 60-99 & 52 & 0.020 & 0.017 & -0.021 & 0.067 \\
GDP per capita growth 80-00 & 58 & 0.015 & 0.022 & -0.057 & 0.063 \\
Private Credit: 60-99 & 52 & 0.415 & 0.302 & 0.048 & 1.477 \\
Private Credit: 80-00 & 58 & 0.245 & 0.161 & 0.025 & 0.894 \\
Growth of Headcount & 58 & 0.008 & 0.131 & -0.209 & 0.389 \\
Growth of Poverty Gap & 58 & 0.012 & 0.187 & -0.314 & 0.570 \\
\hline
\end{tabular}

Panel B:

\begin{tabular}{lccc}
\hline & $\begin{array}{l}\text { Income growth } \\
\text { of poor }\end{array}$ & $\begin{array}{c}\text { GDP per capita } \\
\text { Growth of Gini }\end{array}$ \\
\hline Growth of Gini & $-0.491^{* * *}$ & & \\
GDP per capita growth $60-99$ & $0.805^{* * *}$ & -0.072 & \\
Private Credit: $60-99$ & $0.620^{* * *}$ & -0.206 & $0.646^{* * *}$ \\
\hline
\end{tabular}

$* * *, * *$ and $*$ represent significance at 1,5 and $10 \%$ level respectively.

Panel C:

\begin{tabular}{lccc}
\hline & $\begin{array}{l}\text { Growth of } \\
\text { Headcount }\end{array}$ & $\begin{array}{l}\text { Growth of } \\
\text { Poverty Gap }\end{array}$ & $\begin{array}{c}\text { GDP per capita } \\
\text { growth 80-00 }\end{array}$ \\
\hline Growth of Poverty Gap & $0.934^{* * *}$ & & \\
GDP per capita growth 80-00 & -0.125 & -0.129 & \\
Private Credit: $80-00$ & $-0.411^{* * *}$ & $-0.349 * * *$ & 0.221 \\
\hline$* * * * *$
\end{tabular}

$* * *, * *$ and $*$ represent significance at 1,5 and $10 \%$ level respectively. 


\section{Table 3: Finance and Income Growth of the Poor}

The dependent variable is Income Growth of the Poor, which equals the annual growth rate in the income per capita of the poorest quintile over the period 1960-1999. The regressors are as follows. Initial Income of the Poor equals the logarithm of the initial level of income per capita of the poorest quintile (e.g., 1960 data). GDP per capita growth equals the growth rate of real GDP per capita over the period 1960-1999. Trade Openness equals the logarithm of the share of exports plus imports relative to GDP averaged over the period 1960-1999. Inflation is the growth rate of the GDP deflator over the period 1960-1999. Schooling 1960 is the logarithm of secondary school attainment from the Barro-Lee dataset in 1960. Private Credit equals the logarithm of claims of financial institutions on the private sector as a share of GDP averaged over the period 1960-1999. Specifications (1) - (3) are estimated using OLS with heteroskedasticity-consistent standard errors. Specifications (4)-(7) are estimated using two-stage least squares with heteroskedasticity consistent standard errors, where instrumental variables are used for Private Credit. The instrumental variables are three dummy variables for the legal origin of the country and the country's latitude. Specifically, Common, French and German equal one for countries with the respective legal origin and zero otherwise. Latitude is the absolute value of the capital city's latitude. Robust standard errors are reported in parentheses. Specifications (1) - (3) report the regression R-squared. Specifications (4) - (7) report the first-stage R-squared and the test of the over-identifying restrictions (OIR test), which tests the null hypothesis that the instruments are uncorrelated with the residuals of the second stage regression. Detailed variable definitions and sources are in the appendix.

\begin{tabular}{|c|c|c|c|c|c|c|c|}
\hline & 1 & 2 & 3 & 4 & 5 & 6 & 7 \\
\hline & $\begin{array}{l}\text { Income } \\
\text { Growth of } \\
\text { the Poor }\end{array}$ & $\begin{array}{l}\text { Income } \\
\text { Growth of } \\
\text { the Poor }\end{array}$ & $\begin{array}{l}\text { Income } \\
\text { Growth of } \\
\text { the Poor }\end{array}$ & $\begin{array}{l}\text { Income } \\
\text { Growth of } \\
\text { the Poor }\end{array}$ & $\begin{array}{l}\text { Income } \\
\text { Growth of } \\
\text { the Poor }\end{array}$ & $\begin{array}{l}\text { Income } \\
\text { Growth of } \\
\text { the Poor }\end{array}$ & $\begin{array}{l}\text { Income } \\
\text { Growth of } \\
\text { the Poor }\end{array}$ \\
\hline $\begin{array}{l}\text { Initial income of the } \\
\text { poor }\end{array}$ & $\begin{array}{c}-0.009 * * * \\
{[0.003]}\end{array}$ & $\begin{array}{c}-0.005^{* *} \\
{[0.002]}\end{array}$ & & & $\begin{array}{l}-0.011^{*} \\
{[0.006]}\end{array}$ & $\begin{array}{c}-0.011 \\
{[0.006]}\end{array}$ & $\begin{array}{c}-0.017 \\
{[0.010]}\end{array}$ \\
\hline GDP per capita growth & & $\begin{array}{c}0.777 * * * \\
{[0.119]}\end{array}$ & $\begin{array}{c}0.852 * * * \\
{[0.113]}\end{array}$ & $\begin{array}{c}0.583 * * \\
{[0.223]}\end{array}$ & $\begin{array}{c}0.429 \\
{[0.307]}\end{array}$ & $\begin{array}{c}0.408 \\
{[0.375]}\end{array}$ & $\begin{array}{c}-0.007 \\
{[0.587]}\end{array}$ \\
\hline Private Credit & $\begin{array}{c}0.031 * * * \\
{[0.005]}\end{array}$ & $\begin{array}{c}0.016 * * * \\
{[0.005]}\end{array}$ & $\begin{array}{c}0.011 * * \\
{[0.004]}\end{array}$ & $\begin{array}{c}0.021 * * * \\
{[0.007]}\end{array}$ & $\begin{array}{c}0.032 * * \\
{[0.013]}\end{array}$ & $\begin{array}{c}0.033 * * \\
{[0.017]}\end{array}$ & $\begin{array}{c}0.047 * * \\
{[0.023]}\end{array}$ \\
\hline Trade Openness & & & & & $\begin{array}{c}-0.004 \\
{[0.004]}\end{array}$ & & \\
\hline Inflation & & & & & & $\begin{array}{c}0.003 \\
{[0.003]}\end{array}$ & \\
\hline Schooling 1960 & & & & & & & $\begin{array}{c}-0.001 \\
{[0.003]}\end{array}$ \\
\hline Constant & $\begin{array}{c}0.099 * * * \\
{[0.018]} \\
\end{array}$ & $\begin{array}{c}0.043^{* * *} \\
{[0.016]} \\
\end{array}$ & $\begin{array}{c}0.014 * * \\
{[0.006]} \\
\end{array}$ & $\begin{array}{l}0.030 * * \\
{[0.012]}\end{array}$ & $\begin{array}{c}0.116 * * \\
{[0.056]}\end{array}$ & $\begin{array}{l}0.095 * \\
{[0.053]}\end{array}$ & $\begin{array}{l}0.154 * \\
{[0.086]}\end{array}$ \\
\hline Estimation Procedure: & OLS & OLS & OLS & IV & IV & IV & IV \\
\hline R-squared & 0.588 & 0.726 & 0.713 & & & & \\
\hline R-squared (1 $1^{\text {st }}$ stage $)$ & & & & 0.597 & 0.743 & 0.756 & 0.721 \\
\hline OIR Test (p-values) & & & & 0.364 & 0.1377 & 0.1132 & 0.5111 \\
\hline Observations & 52 & 52 & 52 & 52 & 52 & 52 & 48 \\
\hline
\end{tabular}

***, ** and * represent significance at 1,5 and $10 \%$ level respectively 


\section{Table 4: Finance and Changes in Income Distribution}

The dependent variable is Growth of Gini, which equals the annual growth rate in the Gini coefficient over the period 1960-1999. The regressors are as follows. Initial Gini equals the logarithm of the value of the Gini coefficient in 1960. GDP per capita growth equals the growth rate of real GDP per capita over the period 1960-1999. Private Credit equals the logarithm of claims of financial institutions on the private sector as a share of GDP averaged over the period 1960-1999. Trade Openness equals the logarithm of the share of exports plus imports relative to GDP averaged over the period 1960-1999. Inflation is the growth rate of the GDP deflator over the period 1960-1999. Schooling 1960 is the logarithm of secondary school attainment from the Barro-Lee dataset in 1960. Specification (1) is estimated using OLS with heteroskedasticity-consistent standard errors. Specifications (2) - (5) are estimated using two-stage least squares with heteroskedasticity-consistent standard errors, where instrumental variables are used for Private Credit. The instrumental variables are three dummy variables for legal origin of the country and the country's latitude. Specifically, Common, French and German equal one for countries with the respective legal origin and zero otherwise. Latitude is the absolute value of the capital city's latitude. Specification (1) reports the regression R-squared. Specifications (2) - (5) report the first-stage Rsquared and the test of the over-identifying restrictions (OIR test), which tests the null hypothesis that the instruments are uncorrelated with the residuals of the second stage regression. Detailed variable definitions and sources are in the appendix.

\begin{tabular}{|c|c|c|c|c|c|}
\hline & 1 & 2 & 3 & 4 & 5 \\
\hline & Growth of Gini & Growth of Gini & Growth of Gini & Growth of Gini & Growth of Gini \\
\hline \multirow[t]{2}{*}{ Initial Gini } & $-0.013 * * *$ & $-0.023 * * *$ & $-0.023 * * *$ & $-0.019 * * *$ & $-0.020 * * *$ \\
\hline & $(0.003)$ & $(0.007)$ & $(0.006)$ & $(0.006)$ & $(0.006)$ \\
\hline \multirow[t]{2}{*}{ GDP per capita growth } & 0.044 & $0.314 * *$ & $0.220 * *$ & $0.280 * *$ & $0.295^{* *}$ \\
\hline & $(0.051)$ & $(0.135)$ & $(0.100)$ & $(0.128)$ & $(0.138)$ \\
\hline \multirow[t]{2}{*}{ Private Credit } & $-0.004 * * *$ & $-0.015 * * *$ & $-0.013 * * *$ & $-0.015 * * *$ & $-0.015^{* * *}$ \\
\hline & $(0.001)$ & $(0.005)$ & $(0.004)$ & $(0.005)$ & $(0.005)$ \\
\hline \multirow[t]{2}{*}{ Trade Openness } & & & 0.003 & & \\
\hline & & & $(0.002)$ & & \\
\hline \multirow[t]{2}{*}{ Inflation } & & & & -0.002 & \\
\hline & & & & $(0.002)$ & \\
\hline \multirow[t]{2}{*}{ Schooling 1960} & & & & & $0.003^{*}$ \\
\hline & & & & & $(0.002)$ \\
\hline \multirow[t]{2}{*}{ Constant } & $0.041 * * *$ & $0.063^{* * *}$ & $0.053 * * *$ & $0.053 * * *$ & $0.053 * * *$ \\
\hline & $(0.012)$ & $(0.021)$ & $(0.020)$ & $(0.019)$ & $(0.017)$ \\
\hline Estimation Procedure: & OLS & IV & IV & IV & IV \\
\hline OIR Test & & 0.744 & 0.347 & 0.440 & 0.258 \\
\hline Observations & 52 & 52 & 52 & 52 & 48 \\
\hline R-squared & 0.212 & & & & \\
\hline R-squared (1 $1^{\text {st }}$ stage $)$ & & 0.607 & 0.665 & 0.660 & 0.670 \\
\hline
\end{tabular}

***, ** and * represent significance at 1, 5 and $10 \%$ level respectively 


\section{Table 5: Finance and Poverty Alleviation}

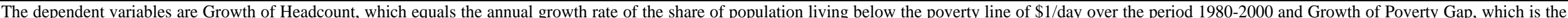
annual growth rate in the e mean shortfall from the poverty line of $\$ 1$ day expressed as a percentage of the poverty line over the period $1980-2000$.

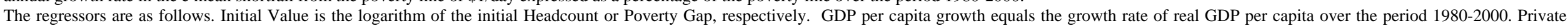

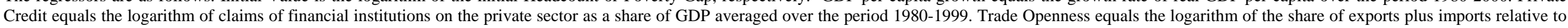

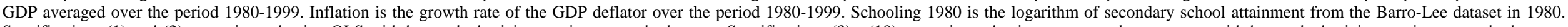

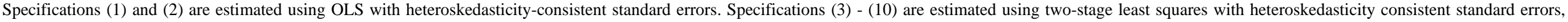

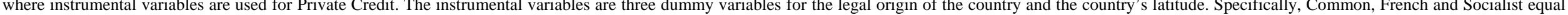

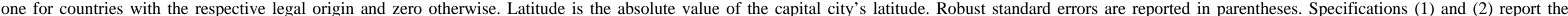

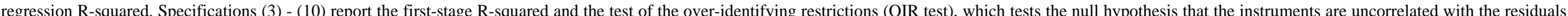
of the second stage regression. Detailed variable definitions and sources are in the appendix.

\begin{tabular}{|c|c|c|c|c|c|c|c|c|c|c|}
\hline & 1 & 2 & 3 & 4 & 5 & 6 & 7 & 8 & 9 & 10 \\
\hline & $\begin{array}{l}\text { Growth of } \\
\text { Headcount }\end{array}$ & $\begin{array}{c}\text { Growth of } \\
\text { Poverty Gap }\end{array}$ & $\begin{array}{l}\text { Growth of } \\
\text { Headcount }\end{array}$ & $\begin{array}{c}\text { Growth of } \\
\text { Poverty Gap }\end{array}$ & $\begin{array}{l}\text { Growth of } \\
\text { Headcount }\end{array}$ & $\begin{array}{c}\text { Growth of } \\
\text { Poverty Gap }\end{array}$ & $\begin{array}{l}\text { Growth of } \\
\text { Headcount }\end{array}$ & $\begin{array}{c}\text { Growth of } \\
\text { Poverty Gap }\end{array}$ & $\begin{array}{l}\text { Growth of } \\
\text { Headcount }\end{array}$ & $\begin{array}{c}\text { Growth of } \\
\text { Poverty Gap }\end{array}$ \\
\hline Initial Value & $\begin{array}{c}-0.035^{* * * *} \\
(0.011)\end{array}$ & $\begin{array}{c}-0.053^{* * * *} \\
(0.015)\end{array}$ & $\begin{array}{c}-0.041 * * * \\
(0.012)\end{array}$ & $\begin{array}{c}-0.055^{* * * *} \\
(0.017)\end{array}$ & $\begin{array}{c}-0.040 * * * \\
(0.011)\end{array}$ & $\begin{array}{c}-0.056 * * * \\
(0.017)\end{array}$ & $\begin{array}{c}-0.041^{* * *} \\
(0.014)\end{array}$ & $\begin{array}{c}-0.055^{* * * *} \\
(0.020)\end{array}$ & $\begin{array}{c}-0.036 * * \\
(0.016)\end{array}$ & $\begin{array}{c}-0.054 * * \\
(0.026)\end{array}$ \\
\hline GDP per capita growth & $\begin{array}{l}-0.934 \\
(0.625)\end{array}$ & $\begin{array}{l}-1.516^{*} \\
(0.891)\end{array}$ & $\begin{array}{l}-0.778 \\
(0.678)\end{array}$ & $\begin{array}{l}-1.492 \\
(0.903)\end{array}$ & $\begin{array}{l}-0.779 \\
(0.778)\end{array}$ & $\begin{array}{l}-1.358 \\
(0.992)\end{array}$ & $\begin{array}{l}-0.784 \\
(0.704)\end{array}$ & $\begin{array}{l}-1.496 \\
(0.952)\end{array}$ & $\begin{array}{l}-1.468 \\
(0.998)\end{array}$ & $\begin{array}{l}-2.008 \\
(1.493)\end{array}$ \\
\hline Private Credit & $\begin{array}{c}-0.095^{* * *} \\
(0.020)\end{array}$ & $\begin{array}{c}-0.133^{* * *} \\
(0.028)\end{array}$ & $\begin{array}{c}-0.163 * * * \\
(0.034)\end{array}$ & $\begin{array}{c}-0.148 * * \\
(0.062)\end{array}$ & $\begin{array}{c}-0.158^{* * *} \\
(0.032)\end{array}$ & $\begin{array}{c}-0.147 * * \\
(0.055)\end{array}$ & $\begin{array}{c}-0.161^{* * *} \\
(0.038)\end{array}$ & $\begin{array}{c}-0.146^{* *} \\
(0.068)\end{array}$ & $\begin{array}{c}-0.112^{* *} \\
(0.044)\end{array}$ & $\begin{array}{l}-0.048 \\
(0.079)\end{array}$ \\
\hline Trade Openness & & & & & $\begin{array}{l}-0.002 \\
(0.034)\end{array}$ & $\begin{array}{l}-0.019 \\
(0.046)\end{array}$ & & & & \\
\hline Inflation & & & & & & & $\begin{array}{c}-3.69 \mathrm{E}-05 \\
(0.015)\end{array}$ & $\begin{array}{c}-1.40 \mathrm{E}-04 \\
(0.020)\end{array}$ & & \\
\hline Schooling 1980 & & & & & & & & & $\begin{array}{c}0.010 \\
(0.040)\end{array}$ & $\begin{array}{l}-0.045 \\
(0.060)\end{array}$ \\
\hline Constant & $\begin{array}{l}-0.059 \\
(0.040) \\
\end{array}$ & $\begin{array}{c}-0.131 * * \\
(0.051) \\
\end{array}$ & $\begin{array}{c}-0.159 * * * \\
(0.058) \\
\end{array}$ & $\begin{array}{l}-0.154 \\
(0.098)\end{array}$ & $\begin{array}{l}-0.143 \\
(0.153) \\
\end{array}$ & $\begin{array}{l}-0.078 \\
(0.223) \\
\end{array}$ & $\begin{array}{c}-0.155^{* *} \\
(0.069) \\
\end{array}$ & $\begin{array}{l}-0.151 \\
(0.099) \\
\end{array}$ & $\begin{array}{l}-0.092 \\
(0.098)\end{array}$ & $\begin{array}{c}0.052 \\
(0.146) \\
\end{array}$ \\
\hline Estimation Procedure: & OLS & OLS & IV & IV & IV & IV & IV & IV & IV & IV \\
\hline OIR Test & & & 0.514 & 0.503 & 0.485 & 0.538 & 0.504 & 0.500 & 0.623 & 0.678 \\
\hline Observations & 58 & 58 & 58 & 58 & 58 & 58 & 58 & 58 & 47 & 47 \\
\hline R-squared & 0.387 & 0.362 & & & & & & & & \\
\hline R-squared (1 $1^{\text {st }}$ stage $)$ & & & 0.329 & 0.377 & 0.399 & 0.452 & 0.358 & 0.402 & 0.303 & 0.353 \\
\hline
\end{tabular}


Figure 1: Partial Scatter Plot of Income Growth of the Poor against Private Credit

Using regression 2 of Table 3, which regresses Income Growth of the Poor against GDP per capita Growth, log of Initial Income of the Poor and Private Credit, this figure represents the twodimensional representation of the regression plane in Income Growth of the Poor - Private Credit space. To obtain this figure, we regress Income Growth of the Poor on GDP per capita Growth and log of Initial Income of the Poor, collect the residuals, and call them e(Income Growth of the Poor | $\mathrm{X}$ ). Next, we regress Private Credit against GDP per capita Growth and log of Initial Income of the Poor, collect the residuals, and call them e(Private Credit $\mid X)$. Then, we plot e(Income Growth of the Poor $\mid \mathrm{X})$ against e(Private Credit $\mid \mathrm{X}$ ).

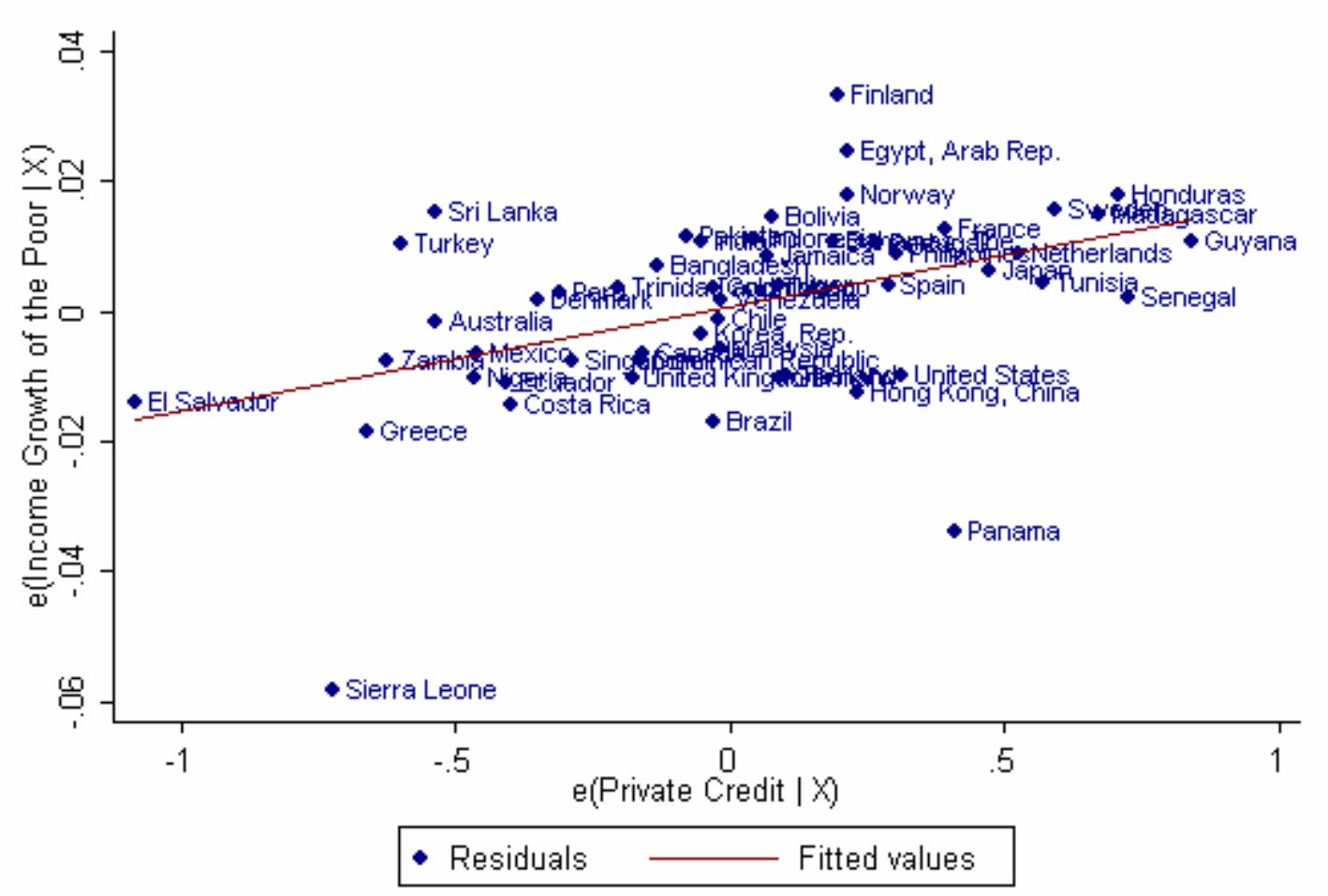




\section{Figure 2: Partial Scatter Plot of Growth of Gini against Private Credit}

Using regression 1 of Table 4, which regresses Growth of Gini against log of initial Gini, GDP per capita Growth and Private Credit, this figure represents the two-dimensional representation of the regression plane in Growth of Gini - Private Credit space. To obtain this figure, we regress Growth of Gini on log of initial Gini and GDP per capita Growth, collect the residuals, and call them (Growth of Gini |X). Next, we regress Private Credit against log of initial Gini and GDP per capita Growth, collect the residuals, and call them e(Private Credit |X ). Then, we plot e(Growth of Gini | $\mathrm{X}$ ) against $\mathrm{e}$ (Private Credit | X).

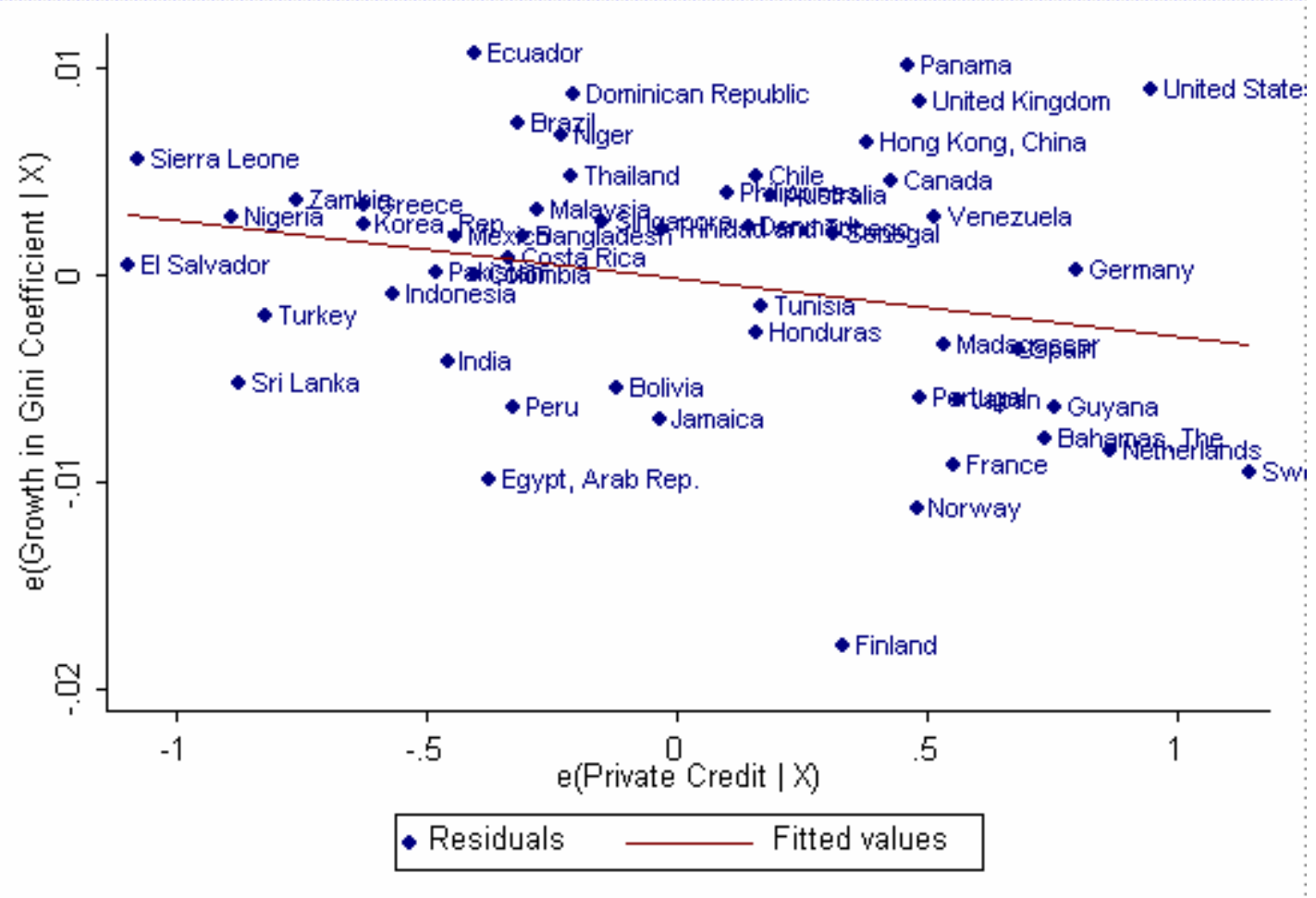


Figure 3: Partial Scatter Plot of Growth of Headcount against Private Credit

Using regression 1 of Table 5, which regresses Growth of Headcount against log of initial Headcount, GDP per capita Growth and Private Credit, this figure represents the two-dimensional representation of the regression plane in Growth of Headcount - Private Credit space. To obtain this figure, we regress Growth of Headcount on log of initial Headcount and GDP per capita Growth, collect the residuals, and call them (Growth of Headcount $\mid X$ ). Next, we regress Private Credit against log of initial Headcount and GDP per capita Growth, collect the residuals, and call them e(Private Credit $\mid X$ ). Then, we plot e(Growth of Headcount |X) against e(Private Credit |X).

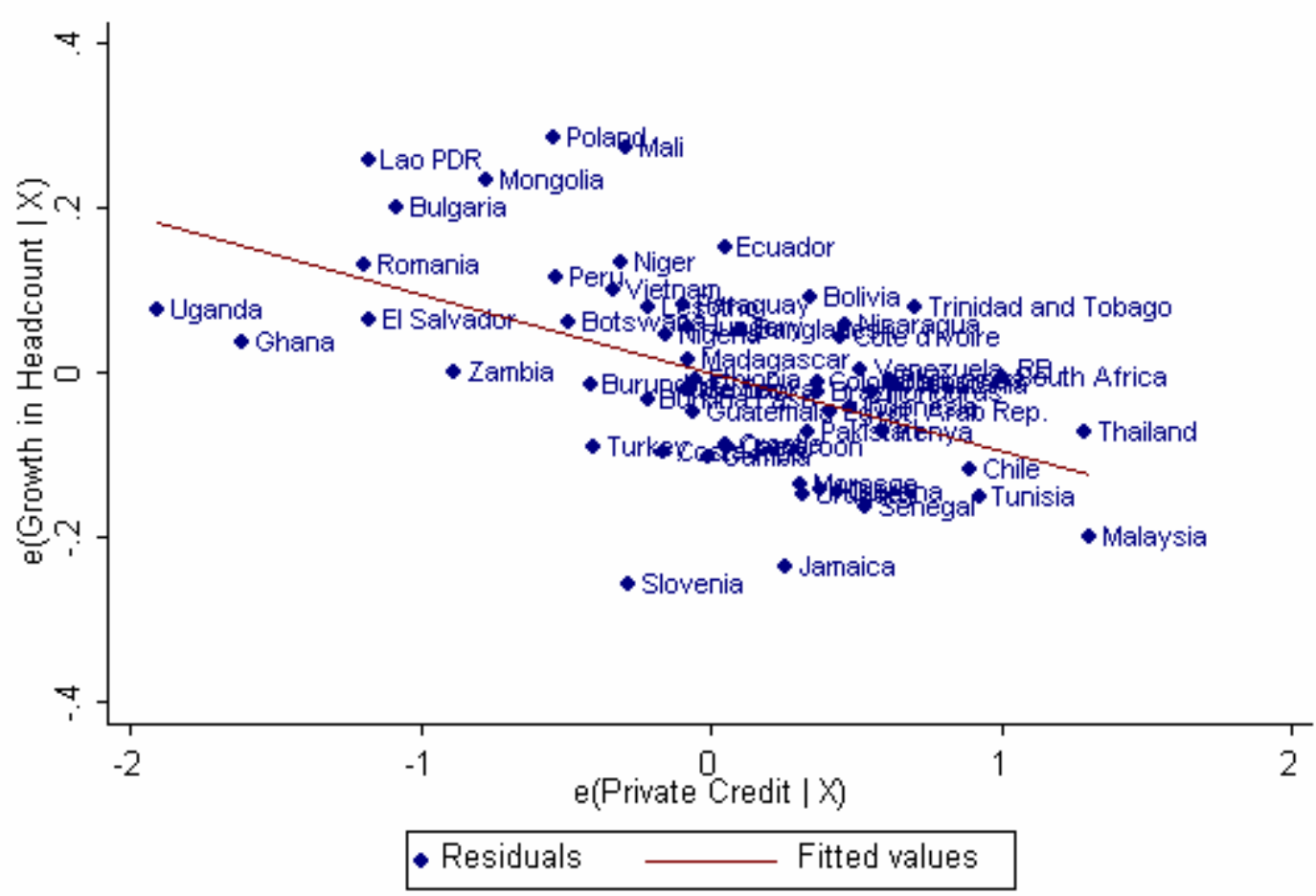




\section{Appendix: Variable Definitions}

Variable
Income Growth of the Poor

Growth of Gini

Growth of Headcount

Growth of Poverty Gap

GDP per capita

GDP per capita Growth

Private Credit

Schooling in 1960/1980

Inflation

Trade Openness

Latitude

Common

French

German
Variable Definition

Source

GDP per capita growth of the lowest income quintile group

World Development Indicators (WDI)

Dollar and Kraay (2002)

The Gini coefficient is the ratio of the area between the Lorenz Curve, which plots share Dollar and Kraay (2002)

of population against income share received, to the area below the diagonal. It lies

between 0 and 1 , where 0 is perfect equality and 1 is perfect inequality. The growth rate

is calculated as the log difference between the last and the first available observations,

divided by the number of years.

Headcount is the percentage of the population living below the national poverty line, as defined as living on $\$ 1$ a day. The growth rate is calculated as the log difference

between the last and the first available observations, divided by the number of years.

The poverty gap is defined as the mean shortfall from the poverty line, expressed as a percentage of the poverty line. The growth rate is calculated as the log difference between the last and the first available observations, divided by the number of years.

GDP per capita in constant 1995 US\$

GDP per capita growth, annual \%

The claims on private sector by deposit money banks and other financial institutions as a share of GDP

The logarithm of the average years of school attainment in 1960 or 1980

The growth rate of the GDP deflator

The logarithm of the share of imports plus exports in GDP

The absolute value of the latitude of the country, scaled to take values between 0 and 1

A dummy variable that takes on a value of one if the origin of the country's legal system is British and zero otherwise.

Povcal Net, World Bank

Dollar and Kraay (2002)

WDI

WDI, Dollar and Kraay (2002)

IFS, own calculations

Barro-Lee dataset; Barro and Lee (1993)

WDI

WDI

La Porta, Lopez-de-Silanes, Shleifer, and Vishny (henceforth LLSV, 1999)

LLSV (1999)

LLSV (1999) system is French and zero otherwise.

A dummy variable that takes on a value of one if the origin of the country's legal system is German and zero otherwise.
LLSV (1999) 
